\title{
Liandratite from Karkonosze pegmatites, Sudetes, Southwestern Poland
}

\author{
Witold Matyszczak ${ }^{1}$
}

Received: 7 October 2015 / Accepted: 11 October 2017 /Published online: 6 November 2017

(C) The Author(s) 2017. This article is an open access publication

\begin{abstract}
The chemical composition of liandratite, $\mathrm{U}^{6+}(\mathrm{Nb}, \mathrm{Ta})_{2} \mathrm{O}_{8}$, was determined from material collected in Niobium, Yttrium, Fluorine type (NYF) pegmatites of the Karkonosze intrusion (Sudetes, SW Poland). Liandratite occurs mainly as rims, up to $40 \mu \mathrm{m}$ thick, and fracture infillings in fergusonite-(Y) and other Nb-Ta-Ti minerals. Its formation was related to the fluid-driven alteration of primary minerals by three potential mechanisms: (i) direct replacement of a primary mineral by liandratite; (ii) breakdown of the primary mineral to liandratite and a product with the composition of minerals of the pyrochlore group; (iii) multistage alteration, which involved: removal of A-site cations (mostly $\mathrm{Y}+\mathrm{REE}$ with the exception of $\mathrm{U}^{4+}$ ) and formation of phases with the composition of pyrochlore group minerals; then crystallization of $\mathrm{U}-, \mathrm{Bi}-, \mathrm{Pb}$-rich pyrochlores and their replacement by liandratite. The chemical compositions of liandratite formed by the breakdown of different primary minerals are also different, mainly in their $\mathrm{U}, \mathrm{Ti}$ and $\mathrm{Nb}$ contents. Excess Ti, relative to the $\mathrm{U}^{6+} \mathrm{Nb}_{2} \mathrm{O}_{8}$ end-member, is incorporated into the structure together with additional $\mathrm{U}$. The Ti content of liandratite, and partially through this the $U$ content, are dependent on the nature of the precursor mineral.
\end{abstract}

Editorial handling: F. Gervilla

Electronic supplementary material The online version of this article (https://doi.org/10.1007/s00710-017-0537-8) contains supplementary material, which is available to authorized users.

Witold Matyszczak

witold.matyszczak@uw.edu.pl

1 Institute of Geochemistry, Mineralogy and Petrology, University of Warsaw, 02-089 Warsaw, Poland
Keywords Liandratite $\cdot$ Fergusonite $\cdot$ NYF pegmatite $\cdot$ Granite pegmatite $\cdot$ Karkonosze

\section{Introduction}

Liandratite, with the ideal formula $\mathrm{U}^{6+}(\mathrm{Nb}, \mathrm{Ta})_{2} \mathrm{O}_{8}$, is a rare mineral, first described from the granitic pegmatite Antsakoa I in Madagascar by Mücke and Strunz (1978), where it is an oxidation product of the isostructural petschekite $\mathrm{U}^{4+} \mathrm{Fe}^{2+}(\mathrm{Nb}, \mathrm{Ta})_{2} \mathrm{O}_{8}$. Both phases are metamict and after heating they yield products with $\mathrm{X}$-ray powder diffraction (XRD) patterns similar to that of synthetic $\mathrm{U}^{6+} \mathrm{Ta}_{2} \mathrm{O}_{8}$ (Gasperin 1960), implying the $P \overline{3} 1 \mathrm{~m}$ space group.

Since its first description as a new mineral species, liandratite has only been mentioned by several authors (Lumpkin and Ewing 1996; Lumpkin 2001; Kristiansen 2006; Abd El-Naby 2009; Galliski et al. 2009; Matyszczak 2013, 2014), while chemical data seem to have been presented only by Lumpkin and Ewing (1996). The latter authors found liandratite as a weathering product of betafite $\left(\square, \mathrm{U}^{4+}\right)_{2} \mathrm{Ti}_{2} \mathrm{O}_{6}(\mathrm{O}, \mathrm{OH}, \mathrm{F})$ and analyses revealed that the chemical composition of liandratite is no less complex than those of the other Nb-Ta-Ti oxides.

Liandratite shows a strong compositional similarity to the U-rich member of the pyrochlore group - uranopyrochlore $\left(\square, \mathrm{U}^{4+}\right)_{2} \mathrm{Nb}_{2} \mathrm{O}_{6}(\mathrm{O}, \mathrm{OH}, \mathrm{F})$ (Atencio et al. 2010); however, it has a different $\mathrm{U}$ oxidation state. Unfortunately, to the author's knowledge, uranopyrochlore is still a rather theoretical member of the pyrochlore group because there is currently no species fulfilling the classification criteria proposed by Atencio et al. (2010) for this mineral. Only one analysis in the literature satisfactorily meets the dominant valence rule regarding the $\mathrm{U}$ content in the A-site: analysis 9 from Chibiny (Chakhmouradian and Mitchell 2002). 
"Uranopyrochlore" from the Nechalacho REE deposit (Timofeev and Williams-Jones 2015) can be classified as calciopyrochlore from the prevalent amount of $2^{+}$-valence group cations. Additionally, a single U-rich member of the betafite group, classified as oxyuranobetafite, was described by Mokhov et al. (2008). This paper presents new chemical analyses of liandratite from Karkonosze pegmatites and summarizes the available data on this phase in terms of its chemical similarity to the U-rich pyrochlore-betafite solid solutions.

\section{Geological setting}

\section{Granite}

Karkonosze is a Variscan granitoid pluton located on the northeastern edge of the Bohemian Massif (Fig. 1). It is a postcollisional type pluton, composed mainly of peraluminous, calc- to sub-alkaline granite and considered to be an I- to transitional I/S-type (Mikulski 2007). According to Słaby and Martin (2008) most of the pluton is a product of mixing of acidic crustal melts with mantle-derived mafic melts. Mixing, hybridization and fractional crystallization were involved in the evolution of the pluton.

The pluton is formed of several varieties of granitoids, among which four main types can be distinguished in the
Polish part: (i) Porphyritic coarse- to medium-grained granite is characterized by the presence of K-feldspar phenocrysts a few $\mathrm{cm}$ in size, often mantled by albite or oligoclase, with subordinate hornblende. Traditionally, it has been called the central granite in the Polish section of Karkonosze (Borkowska 1966) and is subdivided into the Jizera and Liberec types in the Czech part (Žák and Klomínský 2007). (ii) Equigranular, medium-grained biotite granite (the Harrachov type; Žák and Klomínský 2007) is composed of $\mathrm{K}$-feldspar, quartz, plagioclase and depleted in hornblende. This variety occurs mainly in the middle of the intrusion and also in the eastern part. (iii) Fine-grained biotite granite is very similar to variety (ii) in composition; this rock is often called the ridge (Borkowska 1966) or Karkonosze granite (Žák and Klomínský 2007). (iv) A subordinate variety granophyric granite is present as small bodies near Jelenia Góra and builds the middle part of the Rudawy Janowickie ridge near Strużnica (Borkowska 1966). In addition to these four main granitoid types, the two-mica granite of Tanvald type (v) is present in the southwestern part of the pluton and the Fojtka granodiorite (vi) is hosted in the porphyritic variety (between the Liberec and Jizera types) in the western part.

Based on chemical abrasion-isotope dilution-thermal ionization mass spectrometry (CA-ID-TIMS) zircon ages, the age of emplacement of the main granite varieties (porphyritic and equigranular) was estimated at ca. $312 \mathrm{Ma}$ (Kryza

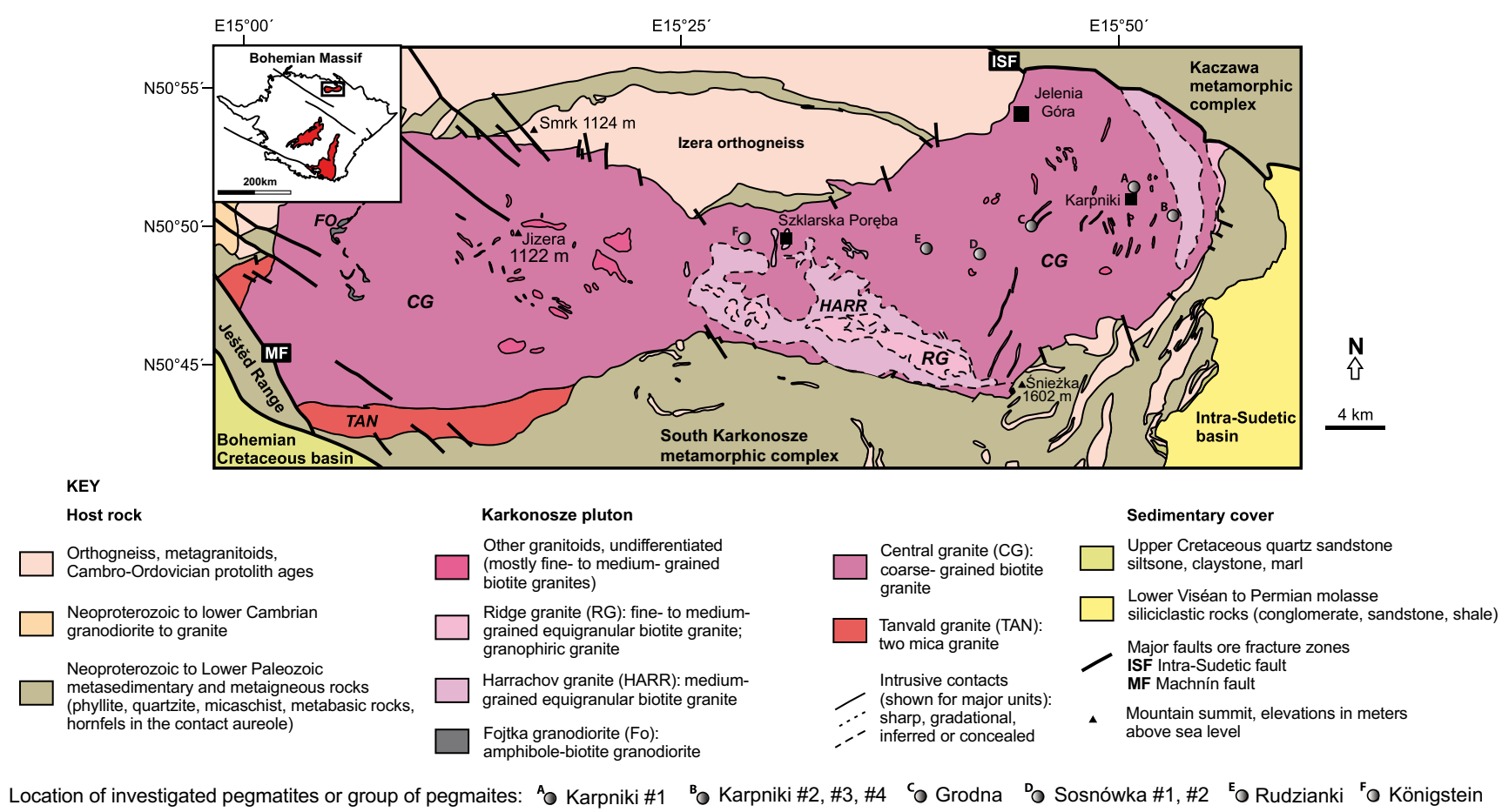

Fig. 1 Location of investigated pegmatites and groups of pegmatites in the Karkononosze pluton. In the general map a red colour is applied to granitoid plutons. Modified after Žák et al. (2013) 
et al. 2014). Detailed information on the Karkonosze pluton is given by Kryza et al. (2014), Žák and Klomínský (2007), Žák et al. (2013); see also references therein.

\section{Pegmatites}

Pegmatites are common in the Karkonosze pluton, although probably a significant part of them were removed by erosion of the upper part of the intrusion, along with the metamorphic cover. They take different forms: ovoidal, globular, lenticular and veins. The size is very variable, from decimetresized nests to bodies several meters long (Kozłowski and Sachanbiński 2007). In the past they were used as feldspar raw material for ceramic production. At the end of the 19th or beginning of the twentieth centuries exploitation ceased and since that time most of the pegmatites have been forgotten.

Six of the investigated pegmatites, Rudzianki \#1, Sosnówka \#1, \#2, Karpniki \#1, \#3 and Königstein, are bodies of significant size. The biggest, Karpniki \#1, is probably tens of meters in length; others are smaller, up to several meters in maximum dimension. The other investigated pegmatites are veins or parts of veins with a thickness of several tens of centimetres. All the investigated pegmatites are hosted in the porphyritic variety of the Karkonosze granite (Fig. 1), with the exception of the Grodna \#1 pegmatite vein which is found in a small occurrence of the equigranular granite type.

The contact between pegmatite and host rock is usually sharp. The border zone is represented by aplite, followed by a fine graphic zone and a blocky K-feldspar (microcline?) zone with quartz toward the core. The whole sequence is complemented by a quartz core (Fig. 2). The presence of these zones depends on the thickness of the pegmatite and usually only large bodies have all the zones well developed. The Sosnówka \#1 and \#2 pegmatites show a biotite schlieren at the contact between pegmatite and host rock.

The mineralogical composition of the pegmatite bodies is rather simple: K-feldspar, quartz, biotite, and less commonly muscovite. Biotite is frequently chloritized. The accessory mineral assemblages are different in almost all the investigated bodies, comprising: fergusonite-( $\mathrm{Y})$ $\mathrm{YNbO}_{4}$, xenotime-(Y) $\mathrm{YPO}_{4} \pm$ monazite group minerals \pm thorite $\mathrm{ThSiO}_{4} \pm$ aeschynite $-(\mathrm{Y}) \mathrm{Y}(\mathrm{Ti}, \mathrm{Nb})_{2} \mathrm{O}_{6} \pm$ polycrase- $(\mathrm{Y}) \mathrm{Y}(\mathrm{Ti}, \mathrm{Nb})_{2} \mathrm{O}_{6} \pm$ allanite- $(\mathrm{Ce})(\mathrm{CaCe})\left(\mathrm{Al}_{2} \mathrm{Fe}^{2+}\right)$ $\mathrm{Si}_{2} \mathrm{O}_{7}\left[\mathrm{SiO}_{4}\right] \mathrm{O}(\mathrm{OH}) \pm$ cassiterite $\mathrm{SnO}_{2} \pm$ wolframite $(\mathrm{Fe}, \mathrm{Mn})$ $\mathrm{WO}_{4} \pm$ scheelite $\mathrm{CaWO}_{4} \pm$ ixiolite $(\mathrm{Ta}, \mathrm{Mn}, \mathrm{Nb}) \mathrm{O}_{2} \pm$ a xenotime-(Y)-chernovite-(Y) solid solution $\mathrm{YPO}_{4}-\mathrm{YAsO}_{4}$. Many grains of the $\mathrm{Nb}$-Ta-Ti oxides are heavily altered and replaced by secondary phases, i.e. liandratite or minerals of the pyrochlore supergroup. The monazite is frequently replaced by cerianite-(Ce). The detailed occurrence of the most important accessory minerals in the pegmatite bodies is presented in Table 1.

Karkonosze pegmatites predominantly fit to the NYF signature sensu Černý and Ercit 2005 (Pieczka et al. 2015), but with very low fluorine content. Despite this and not being hosted by an A-type granite as is typical of this family

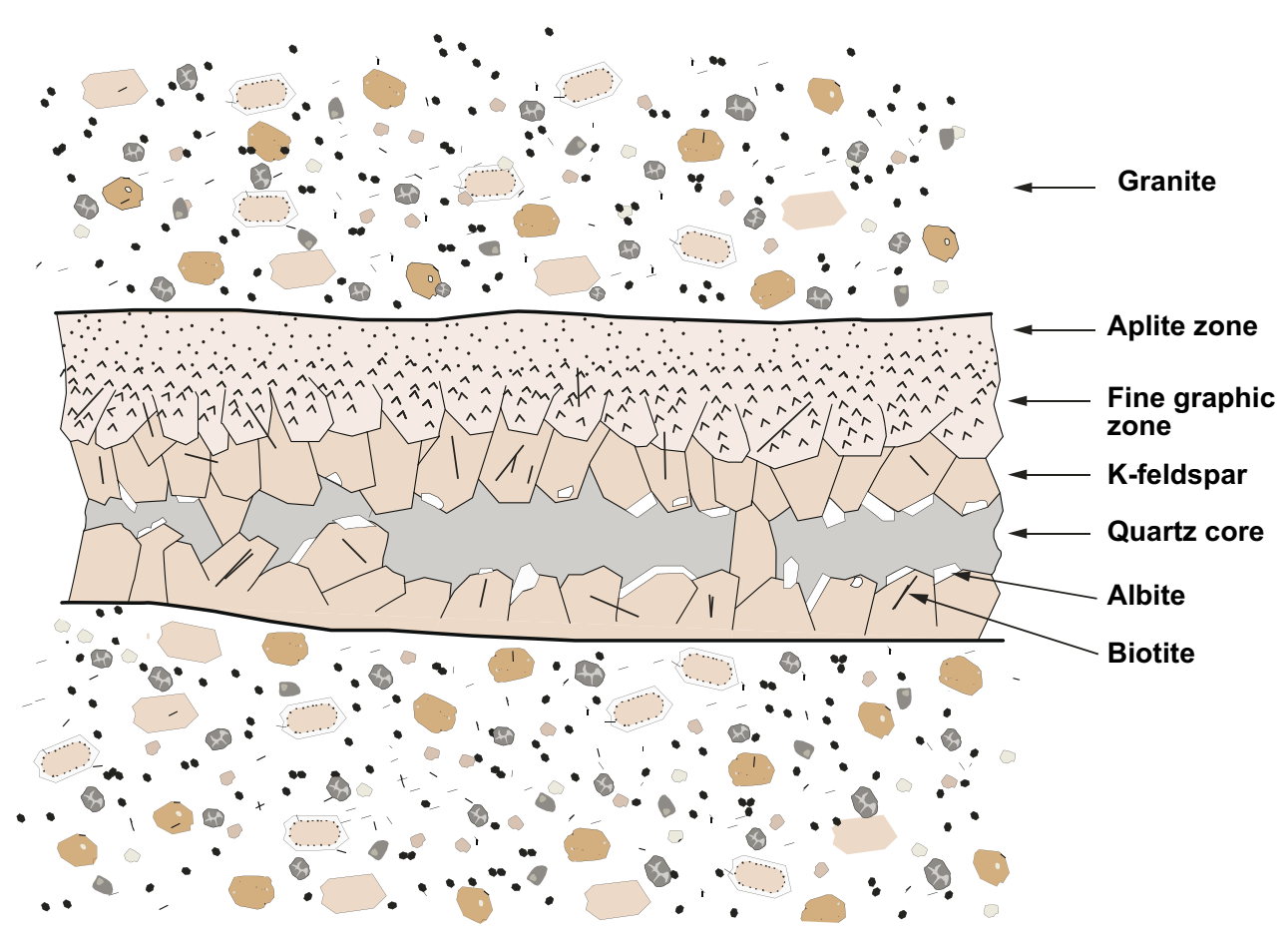

Fig. 2 Schematic sketch of the structure of the investigated pegmatite. The asymmetrical shape does illustrate not always the full development of the typical pegmatite zones. Typical thickness of investigated veins does not exceed $50-60 \mathrm{~cm}$ 
Table 1 Accessory minerals present in investigated Karkonosze pegmatites

\begin{tabular}{|c|c|c|c|c|c|c|c|c|c|}
\hline Mineral & Sosnówka\#1 & Sosnówka\#2 & Rudzianki\#1 & Grodna\#1 & Karpniki\#1 & Karpniki\#2 & Karpniki\#3 & Karpniki\#4 & Königstein \\
\hline Ixiolite & + & $+?$ & ++ & & & & $+?$ & + & + \\
\hline Aeschynite-(Y) & & & & & & & & + & \\
\hline Polycrase-(Y) & & & + & +++ & & & & + & \\
\hline Fergusonite-(Y) & ++ & + & ++++ & & ++ & +++ & +++ & + & \\
\hline $\begin{array}{l}\text { Pyrochlore subgroup } \\
\text { minerals }\end{array}$ & + & + & & & & & & & \\
\hline $\begin{array}{l}\text { Mikrolite subgroup } \\
\text { minerals }\end{array}$ & & & + & & & & & & \\
\hline Uranobetafite & & & & + & & & & & \\
\hline Liandratite & + & + & + & + & + & ++ & +++ & + & + \\
\hline Cerianite-(Ce) & + & + & & & & & & + & \\
\hline Monazite-(Ce) & + & + & & & & & & + & +++ \\
\hline Monazite-(Nd) & ++ & + & & & & ++ & ++ & +++ & \\
\hline Cheralite & ++ & & & & & & & & \\
\hline \multicolumn{10}{|l|}{ Xenotime-(Y) } \\
\hline Arsenian xenotime-(Y) & + & + & + & + & + & + & +++ & + & +++ \\
\hline Chernovite-(Y) & & & & & + & & + & & \\
\hline $\begin{array}{l}\text { Zirconolite or kobeite- } \\
\text { (Y) }\end{array}$ & & & & & & & & + & \\
\hline Allanite-(Ce) & & +++ & + & & & & & + & \\
\hline $\begin{array}{l}\text { Gadolinite-(Y) or } \\
\text { hinganite-(Y) }\end{array}$ & & & + & & + & & & & \\
\hline Cassiterite & & & $+*$ & & $+^{*}$ & & & +++ & \\
\hline Wolframite & & & & & & & & + & \\
\hline Scheelite & & & & & & & + & & \\
\hline
\end{tabular}

+- single grains; ++ - few; +++ -significant number; ++++ -large number ; $*$-micro inclusions; $?$ - uncertain

(Černý and Ercit 2005; Martin and De Vito 2005; Černý et al. 2012), the mineralogical composition of most pegmatite bodies indicates mainly a NYF affiliation. The Karkonosze pegmatites can be assigned in general to the rare element (REL) and miarolitic class pegmatites of the NYF family sensu Černý and Ercit 2005 (Pieczka et al. 2015). Details of the Karkonosze pegmatites are presented in Kozłowski and Sachanbiński (2007), Pieczka et al. (2015) and references therein.

Recent mineralogical studies (Matyszczak 2013) indicate that the investigated liandratite-bearing pegmatites can be assigned with some ambiguity to the euxenite, gadolinite and allanite-monazite type of the REL-REE subclasses sensu Černý and Ercit (2005). The mineralogical composition of the following bodies allows us to ascribe them to the euxenite type: Sosnówka\#1?, Grodna\#1, Karpniki\#2, Karpniki\#3, Karpniki\#4 and Königstein? The presence of gadolinite subgroup minerals in Karpniki\#1 and Rudzianki\#1 pegmatites might suggest an affiliation to the gadolinite type; however only a single grain of these minerals was found. In the localities mentioned, HREE minerals prevail over LREE types (Table 1). The allanite-monazite type is represented only by the Sosnówka \#2 pegmatite, in which allanite-(Ce) together with monazite group minerals seem to be the main REE minerals (Table 1).

\section{Samples and experimental}

\section{Description of samples}

The material for analysis was obtained mostly from dumps in amounts of 3-4 kg from each pegmatite and comprises blocks of K-feldspar, sometimes with gray quartz and altered biotite and rarely with fine muscovite. It probably corresponds to the intermediate pegmatite zone. In the case of pegmatites Karpniki \#2 and \#4 the samples comprise a graphic zone together with subhedral K-feldspar crystals, as a result of the small size of the pegmatite bodies.

After preliminary treatment of the pegmatites (crushing, milling in a disc mill and sieving), heavy minerals were separated in bromoform. Unfortunately, such a preparation usually makes it very difficult, or even impossible, to determine the textural relationships between minerals as well as the morphology of single crystals. Nevertheless, such 
a procedure was necessary to obtain representative heavy mineral samples.

Liandratite is a fairly common $\mathrm{Nb}-\mathrm{Ta}-\mathrm{Ti}$ mineral in the Karkonosze pegmatites. It was found in 9 of the 11 studied localities, which are chiefly in the northeastern part of the pluton (Fig. 1).

Four types of liandratite occurrence can be distinguished: (i) Liandratite is found in rims (up to $40 \mu \mathrm{m}$ thick) and fracture infillings in fergusonite-(Y) (Fig. 3a-b) or in polycrase(Y). The contact between liandratite and the host mineral is usually sharp, without any transition zone. Such a zone is sometimes present, especially on grains showing more advanced replacement (Fig. 3b), and is a result of the alteration of a host mineral ( $\mathrm{Y}+\mathrm{REE}$ loss or substitution by $\mathrm{Ca}$, addition $\mathrm{Si}$, hydration). Both types of replacement can be present simultaneously in the same grain. (ii) There are porous liandratite masses (aggregates?) replacing minerals of the pyrochlore group (Fig. 3c). Although this type of occurrence is less common, replacing a host mineral by liandratite is often followed by alteration of the former to a phase with the composition of the pyrochlore group minerals. Sometimes alteration leads to the formation of $\mathrm{Pb}$-, Bi- or U-bearing pyrochlores associated with liandratite. (iii) Liandratite occurs as inclusions in heavily altered $\mathrm{Nb}-\mathrm{Ta}$-Ti minerals (Fig. 3d). They are tens of micrometers in size and are randomly spread in the host matrix. (iv) $\mathrm{A}$ probably euhedral liandratite crystal was found in one pegmatite; the grain has a triangular form with a maximum dimension of $90 \mu \mathrm{m}$. This crystal was filled with a mineral from the cheralite-huttonite $\mathrm{CaTh}\left(\mathrm{PO}_{4}\right)_{2}-\mathrm{ThSiO}_{4}$ solid solution series (Fig. 3f). In addition to the previously mentioned assemblages, liandratite occurs together with the $\mathrm{Ce}$ and $\mathrm{Nd}$ varieties of monazite, cerianite-(Ce) $(\mathrm{Ce}, \mathrm{Th}) \mathrm{O}_{2}$, xenotime-(Y)-chernovite-(Y) solid solution and allanite(Ce). Note that cassiterite is present in these assemblages less frequently.
Fig. 3 Different occurrences of liandratite from Karkonosze: a, b liandratite replacing fergusonite-(Y), grains LWD-nom-14 and LWD-nom-7 respectively from Karpniki\#3 pegmatite; $\mathbf{c}$ liandratite replacing mineral with the composition of pyrochlore supergroup minerals, grain Sn39 from Sosnówka\#1 pegmatite; $\mathbf{d}$ inclusions of liandratite in mineral with the composition of pyrochlore supergroup minerals, grain Rum3 28 from Rudzianki\#1 pegmatite; e liandratite replacing altered ixiolite, grain Ks-mag-5 from Königstein pegmatite; f large euhedral? liandratite with cheralite within and 3 smaller grains of liandratite present in ixiolite, grain Sn2-5 from Sosnówka\#1 pegmatite. Ld - liandratite, PGM - mineral with the composition of pyrochlore group minerals, $\mathrm{PGM}-\mathrm{Pb}-\mathrm{Pb}$ enriched mineral with the composition of pyrochlore group, $\mathrm{Ch}$ - cheralite, Fgt - fergusonite, aFgt - altered fergusonite, Ixl - ixiolite
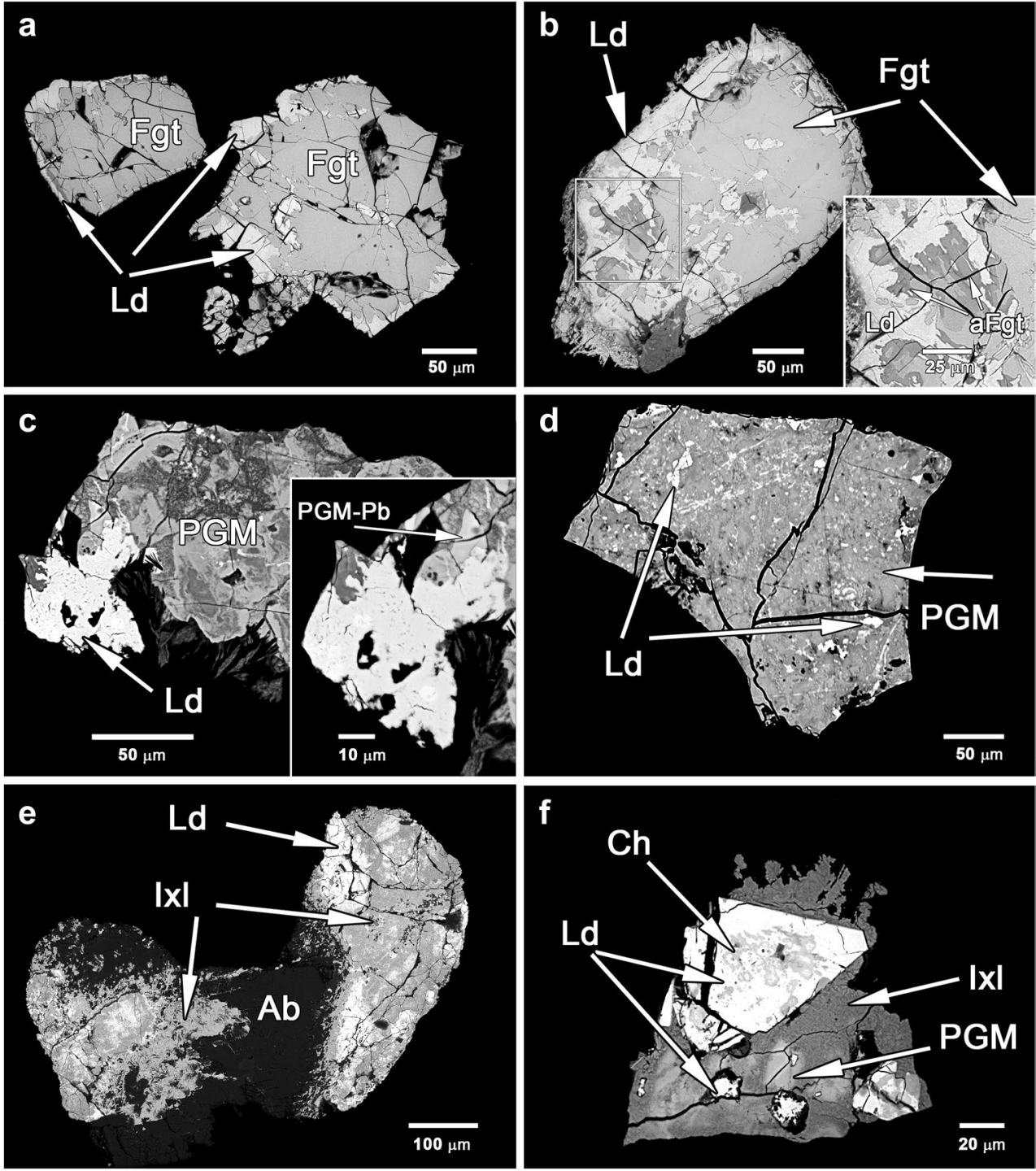


\section{Analytical methods}

Images of samples were obtained using a Jeol JSM-6380 LA scanning electron microscope (SEM). The chemical composition of minerals was determined using a CAMECA SX-100 electron probe micro-analyser (EPMA). The analyses were made with a $15 \mathrm{kV}$ and 20-60 nA beam current, beam diameter $3-5 \mu \mathrm{m}$, peak count time of $30 \mathrm{~s}$ for REE and $20 \mathrm{~s}$ for the other elements and background count time was half of that of the respective peak. The analytical lines, reference materials and detection limits are given in the electronic supplementary material Table S1. The on-line PAP protocol (Pouchou and Pichoir 1985) was applied to the raw data. A distinction between the columbite group minerals and ixiolite was based only on the stoichiometric criterion suggested by Wise et al. (1998) and applied by Beurlen et al. (2007). The name ixiolite was used for samples with more than $10 \mathrm{~mol} \% \mathrm{SnO}_{2}+\mathrm{TiO}_{2}+\mathrm{ZrO}_{2}+\mathrm{HfO}_{2}+\mathrm{Sc}_{2} \mathrm{O}_{3}+\mathrm{Fe}_{2} \mathrm{O}_{3}$.

The term mineral with a composition of the pyrochlore group minerals was applied to (i) the heavily altered $\mathrm{Nb}$-TaTi oxides witch fall in field of "pyrochlore group" minerals of statistical discrimination proposed by Ercit (2005), with high A-site cation deficiency, low totals and usually a high $\mathrm{SiO}_{2}$ content in analyses. The degree of alteration makes us unable to identify their precursors. This group contains samples whose precursors presumably were fergusonite-(Y), aeschynite-euxenite groups minerals or less often ixiolite; (ii) newly formed secondary minerals of the pyrochlore group, enriched in $\mathrm{U}, \mathrm{Pb}$, sometimes in $\mathrm{Bi}$, however still silicified and with A-site cations deficiency, are classified according to Atencio et al. (2010) as zero valence dominant pyrochlore group minerals.

The chemical analyses of liandratite were recalculated on the basis of 8 oxygen atoms per formula unit. All $U$ was treated as $\mathrm{U}^{6+}$ with regard to liandratite and $\mathrm{U}^{4+}$ to ixiolite, polycrase-( $\mathrm{Y})$, fergusonite-(Y) and its alteration products (minerals with the compositions of the pyrochlore group). Total $\mathrm{Fe}$ was assumed to be $\mathrm{Fe}^{3+}$ in the case of liandratite and $\mathrm{Fe}^{2+}$ in the other phases. The only exceptions are analyses shown in the supplementary material Table S2, in which $\mathrm{Fe}$ is presented as published in the cited original.

\section{Results}

\section{General comments}

More than 30 determinations revealed the complex composition of liandratite from the Karkonosze pegmatites. Analytical totals are between 89.5 and $99.7 \mathrm{wt} \%$. The behaviour of liandratite during analysis varied from grain to grain. Usually it was fairly stable under the electron beam; hence parts of the analyses were performed with a beam current up to
60 nA. In some cases, for example in pegmatite Karpniki \#2, a much lower current was used because of the intense mineral decomposition in the area of analysis. Despite using a low current, such analyses often had low totals. A metamict state and related problems, e.g. beam susceptibility, porosity and possibly the presence of water, are often the causes of low totals in this type of mineral. Selected chemical analyses are given in Table 2.

The cation content in the A-site is variable and usually significantly exceeds the theoretical number of cations, reaching up to $1.51 \mathrm{apfu}$. Uranium is the main cation in this position (0.99-1.27 apfu; 49.6-60.0 wt\% $\mathrm{UO}_{3}$ ) but the presence of other cations is notable: $\mathrm{Ca}(0.01-0.19 \mathrm{apfu}$; $0.1-1.80 \mathrm{wt} \% \mathrm{CaO}), \mathrm{Y}\left(\leq 0.05 \mathrm{apfu} ; \leq 0.87 \mathrm{wt} \% \mathrm{Y}_{2} \mathrm{O}_{3}\right)$, $\sum \operatorname{REE}\left(\leq 0.13 \mathrm{apfu} ; \leq 3.6 \mathrm{wt} \% \sum \mathrm{REE}_{2} \mathrm{O}_{3}\right) ; \mathrm{Th}(\leq 0.11 \mathrm{apfu} ;$ $\left.\leq 4.6 \mathrm{wt} \% \mathrm{ThO}_{2}\right)$, $\mathrm{Bi}\left(\leq 0.09 \mathrm{apfu} ; \leq 3.5 \mathrm{wt} \% \mathrm{Bi}_{2} \mathrm{O}_{3}\right)$ and $\mathrm{Pb}$ ( $\leq 0.07 \mathrm{apfu} ; \leq 2.7 \mathrm{wt} \% \mathrm{PbO}$ ).

The B-site occupancy is also variable and, in contrast to the A-site, the cation content is generally slightly (but not always) below the theoretical $2.00 \mathrm{apfu}$, ranging from 1.70 to $2.10 \mathrm{apfu}$. Due to the low content of the main cations occupying this site, it was decided to put $\mathrm{Fe}$ as $\mathrm{Fe}^{3+}$ in this position. Niobium (0.86-1.47 apfu; $19.6-34.1 \mathrm{wt} \%$ $\left.\mathrm{Nb}_{2} \mathrm{O}_{5}\right)$ is dominant over Ti $(0.02-0.59 \mathrm{apfu} ; 0.3-7.8 \mathrm{wt} \%$ $\left.\mathrm{TiO}_{2}\right), \mathrm{Ta}\left(\leq 0.23 \mathrm{apfu} ; \leq 8.4 \mathrm{wt} \% \mathrm{Ta}_{2} \mathrm{O}_{5}\right)$ and $\mathrm{Fe}(0.04-0.18$; 0.55-2.48 wt $\% \mathrm{Fe}_{2} \mathrm{O}_{3}$ ). The content of non-formula elements is high and ranges between 0.27 and 0.73 apfu: $\mathrm{Al}$ (0.02-0.28 apfu; 0.10-0.24 wt $\% \mathrm{Al}_{2} \mathrm{O}_{3}$ ), Si (0.06-0.32 apfu; $\left.0.6-0.32 \mathrm{wt} \% \mathrm{SiO}_{2}\right), \mathrm{P}\left(\leq 0.20 \mathrm{apfu} ; \leq 2.7 \mathrm{wt} \% \mathrm{P}_{2} \mathrm{O}_{5}\right) \mathrm{Zr}$ $\left(\leq 0.1 \mathrm{apfu} ; \leq 2.1 \mathrm{wt} \% \mathrm{ZrO}_{2}\right)$ and $\mathrm{W}(\leq 0.03 \mathrm{apfu} ; 1.2 \mathrm{wt} \%$ $\left.\mathrm{WO}_{3}\right)$.

\section{Chemical composition of the associated minerals}

Liandratite occurs in association with various $\mathrm{Nb}-\mathrm{Ta}-\mathrm{Ti}$ minerals. Most textural relationships between liandratite and associated minerals indicate a direct or indirect replacement of the host mineral by a later phase e.g. Fig. 3a-c, including liandratite as one of the breakdown products of unidentified $\mathrm{Nb}-\mathrm{Ta}-\mathrm{Ti}$ oxide minerals, e.g. Fig. 3d. Representative analyses of possible precursors are given in Table 3 .

Due to the ubiquity of its occurrence, fergusonite- $(\mathrm{Y})$ is apparently the most widespread possible precursor of liandratite in the pegmatites. Its composition and those of other possible precursors are plotted in the system $\mathrm{Nb}$-Ta-Ti in Fig. 4. Fergusonite contains $38.0-44.3 \mathrm{wt} \% \mathrm{Nb}_{2} \mathrm{O}_{5}$ and small amounts of $\mathrm{Ti}\left(0.8-4.4 \mathrm{wt} \% \mathrm{TiO}_{2}\right)$ and $\mathrm{W}(2.5-5.5 \mathrm{wt} \%$ $\left.\mathrm{WO}_{3}\right)$. The Ta content is variable $\left(3.0-17.0 \mathrm{wt} \% \mathrm{Ta}_{2} \mathrm{O}_{5}\right)$ and depends on the locality and degree of alteration. The $\mathrm{UO}_{2}$ content varies between 2.2 and $6.8 \mathrm{wt} \%$.

The next possible precursor, ixiolite, is a rather uncommon mineral in the Karkonosze pegmatites. It is usually altered to some degree and decomposes during analysis. 
Table 2 Representative chemical compositions and calculated formulae of liandratite from various Karkonosze pegmatites

\begin{tabular}{|c|c|c|c|c|c|c|c|c|}
\hline Constituents & Sn39-5 & Sn2-5-5 & Grod-16-4 & Rum3-28-nom-3 & Sn3-15-6 & LWD-nom-14-6 & LWD-nom-3-7 & Range of oxides content \\
\hline \multicolumn{9}{|c|}{ EPMA results (wt\%) } \\
\hline $\mathrm{WO}_{3}$ & 0.18 & 0.10 & 0.11 & 1.02 & 0.00 & 1.22 & 1.13 & $\leq 1.22$ \\
\hline $\mathrm{UO}_{3}$ & 56.69 & 52.72 & 57.98 & 55.81 & 52.55 & 53.52 & 52.05 & $49.15-60.02$ \\
\hline $\mathrm{P}_{2} \mathrm{O}_{5}$ & 0.40 & 1.03 & 1.63 & 0.00 & 0.66 & 0.57 & 2.47 & $\leq 2.47$ \\
\hline $\mathrm{Nb}_{2} \mathrm{O}_{5}$ & 26.62 & 30.25 & 18.52 & 20.15 & 34.10 & 20.98 & 24.43 & $18.12-34.10$ \\
\hline $\mathrm{Ta}_{2} \mathrm{O}_{5}$ & 1.94 & 1.33 & 1.33 & 0.00 & 1.11 & 7.21 & 4.10 & $\leq 8.41$ \\
\hline $\mathrm{SiO}_{2}$ & 1.94 & 1.86 & 1.04 & 1.26 & 2.08 & 2.99 & 1.43 & $0.57-3.19$ \\
\hline $\mathrm{TiO}_{2}$ & 2.46 & 0.73 & 6.94 & 7.37 & 0.26 & 1.19 & 1.83 & $0.26-7.78$ \\
\hline $\mathrm{ZrO}_{2}$ & n.a & n.a & 0.08 & 0.87 & 0.00 & 0.85 & 1.99 & $\leq 2.14$ \\
\hline $\mathrm{SnO}_{2}$ & 0.00 & 0.00 & 0.00 & 0.22 & 0.00 & 0.00 & 0.00 & $\leq 0.28$ \\
\hline $\mathrm{ThO}_{2}$ & 0.00 & 2.62 & 0.05 & 2.70 & 0.00 & 1.73 & 3.36 & $\leq 4.64$ \\
\hline $\mathrm{Al}_{2} \mathrm{O}_{3}$ & 0.68 & 0.99 & 0.50 & 0.15 & 1.14 & 1.82 & 1.35 & $0.14-2.41$ \\
\hline $\mathrm{Fe}_{2} \mathrm{O}_{3}{ }^{\mathrm{a}}$ & 1.85 & 2.45 & 0.63 & 1.41 & 0.61 & 1.28 & 0.94 & $0.55-2.48$ \\
\hline $\mathrm{Y}_{2} \mathrm{O}_{3}$ & 0.00 & 0.00 & 0.13 & 0.36 & n.a & 0.00 & 0.00 & $\leq 0.87$ \\
\hline $\mathrm{REE}_{2} \mathrm{O}_{3}$ & 0.11 & 1.27 & 0.59 & 2.11 & 2.94 & 1.21 & 0.25 & $\leq 3.55$ \\
\hline $\mathrm{Bi}_{2} \mathrm{O}_{3}$ & 3.26 & 1.06 & n.a & n.a & n.a & n.a & n.a & $\leq 3.50$ \\
\hline $\mathrm{CaO}$ & 1.81 & 1.34 & 0.82 & 0.58 & 1.06 & 0.33 & 0.17 & $0.11-1.81$ \\
\hline $\mathrm{MgO}$ & 0.00 & 0.00 & 0.02 & 0.00 & 0.00 & 0.00 & 0.00 & $\leq 0.03$ \\
\hline $\mathrm{MnO}$ & 0.00 & 0.11 & 0.00 & 0.00 & 0.11 & 0.00 & 0.00 & $\leq 0.16$ \\
\hline $\mathrm{SrO}$ & 0.10 & 0.04 & 0.00 & 0.00 & 0.00 & 0.00 & 0.00 & $\leq 0.1$ \\
\hline $\mathrm{PbO}$ & 1.66 & 1.59 & 0.43 & 0.00 & 0.74 & 0.38 & 0.62 & $\leq 2.74$ \\
\hline $\mathrm{Na}_{2} \mathrm{O}$ & n.a & n.a & 0.00 & 0.00 & 0.00 & n.a & n.a & \\
\hline $\mathrm{F}$ & 0.00 & 0.00 & 0.00 & 0.00 & 0.00 & 0.00 & 0.00 & \\
\hline Total & 99.70 & 99.49 & 90.80 & 94.01 & 97.36 & 95.28 & 96.12 & \\
\hline \multicolumn{9}{|c|}{ Calculated formulae (apfu) ${ }^{\mathrm{b}}$} \\
\hline $\mathrm{W}^{6+}$ & 0.005 & 0.002 & 0.003 & 0.027 & 0.000 & 0.032 & 0.029 & $\leq 0.03$ \\
\hline $\mathrm{P}^{5+}$ & 0.033 & 0.083 & 0.143 & 0.000 & 0.053 & 0.048 & 0.203 & 0.20 \\
\hline $\mathrm{Nb}^{5+}$ & 1.163 & 1.300 & 0.863 & 0.929 & 1.467 & 0.952 & 1.073 & $0.83-1.47$ \\
\hline $\mathrm{Ta}^{5+}$ & 0.051 & 0.034 & 0.037 & 0.000 & 0.029 & 0.197 & 0.108 & $\leq 0.20$ \\
\hline $\mathrm{Si}^{4+}$ & 0.187 & 0.177 & 0.107 & 0.129 & 0.197 & 0.300 & 0.139 & $0.06-0.32$ \\
\hline $\mathrm{Ti}^{4+}$ & 0.179 & 0.052 & 0.538 & 0.565 & 0.019 & 0.090 & 0.134 & $0.02-0.59$ \\
\hline $\mathrm{Zr}^{4+}$ & 0.000 & 0.000 & 0.004 & 0.043 & 0.000 & 0.041 & 0.094 & $\leq 0.10$ \\
\hline $\mathrm{Sn}^{4+}$ & 0.000 & 0.000 & 0.000 & 0.009 & 0.000 & 0.000 & 0.000 & 0.01 \\
\hline $\mathrm{Al}^{3+}$ & 0.077 & 0.111 & 0.061 & 0.017 & 0.128 & 0.216 & 0.154 & $0.02-0.28$ \\
\hline $\mathrm{Fe}^{3+}$ & 0.135 & 0.175 & 0.049 & 0.108 & 0.043 & 0.097 & 0.069 & $0.04-0.18$ \\
\hline $\operatorname{Sum} B$ & 1.830 & 1.934 & 1.805 & 1.827 & 1.936 & 1.973 & 2.003 & \\
\hline $\mathrm{U}^{6+}$ & 1.152 & 1.053 & 1.256 & 1.195 & 1.050 & 1.129 & 1.063 & $0.98-1.28$ \\
\hline $\mathrm{Th}^{4+}$ & 0.000 & 0.057 & 0.001 & 0.063 & 0.000 & 0.039 & 0.074 & $\leq 0.10$ \\
\hline $\mathrm{Y}^{3+}$ & 0.000 & 0.000 & 0.007 & 0.019 & 0.000 & 0.000 & 0.000 & $\leq 0.05$ \\
\hline $\mathrm{REE}^{3+}$ & 0.004 & 0.043 & 0.022 & 0.076 & 0.101 & 0.044 & 0.009 & $\leq 0.13$ \\
\hline $\mathrm{Bi}^{3+}$ & 0.081 & 0.026 & 0.000 & 0.000 & 0.000 & 0.000 & 0.000 & $\leq 0.09$ \\
\hline $\mathrm{Mg}^{2+}$ & 0.000 & 0.000 & 0.003 & 0.000 & 0.000 & 0.000 & 0.000 & $\leq 0.004$ \\
\hline $\mathrm{Ca}^{2+}$ & 0.188 & 0.136 & 0.091 & 0.064 & 0.108 & 0.036 & 0.017 & $0.01-0.19$ \\
\hline $\mathrm{Mn}^{2+}$ & 0.000 & 0.009 & 0.000 & 0.000 & 0.009 & 0.000 & 0.000 & $\leq 0.01$ \\
\hline $\mathrm{Sr}^{2+}$ & 0.056 & 0.002 & 0.000 & 0.000 & 0.000 & 0.000 & 0.000 & $\leq 0.056$ \\
\hline $\mathrm{Pb}^{2+}$ & 0.043 & 0.041 & 0.012 & 0.000 & 0.019 & 0.010 & 0.016 & $\leq 0.07$ \\
\hline
\end{tabular}


Table 2 (continued)

\begin{tabular}{lllllllll}
\hline Constituents & Sn39-5 & Sn2-5-5 & Grod-16-4 & Rum3-28-nom-3 & Sn3-15-6 & LWD-nom-14-6 & LWD-nom-3-7 & Range of oxides content \\
\hline $\mathrm{Na}^{+}$ & 0.000 & 0.000 & 0.000 & 0.000 & 0.000 & 0.000 & 0.000 & 1.179 \\
Sum $A$ & 1.524 & 1.367 & 1.392 & 1.417 & 1.287 & 1.258 & 1. \\
\hline
\end{tabular}

Sum $B: \mathrm{W}+\mathrm{P}+\mathrm{Nb}+\mathrm{Ta}+\mathrm{Ti}+\mathrm{Si}+\mathrm{Zr}+\mathrm{Sn}+\mathrm{Al}+\mathrm{Fe}^{3+}$

Sum $A: \mathrm{U}^{6+}+\mathrm{Th}+\mathrm{YREE}+\mathrm{Bi}+\mathrm{Mg}+\mathrm{Ca}+\mathrm{Mn}+\mathrm{Sr}+\mathrm{Pb}+\mathrm{Na}$

Note: $\mathrm{F}$ and $\mathrm{Na}$ were below the detection limits in all analyses

n.a. not analysed

${ }^{\text {a }}$ Total content of $\mathrm{Fe}$ is calculated as $\mathrm{Fe}_{2} \mathrm{O}_{3}$

${ }^{\mathrm{b}}$ Calculated based on $8 \mathrm{O}=8$ apfu (atoms per formula unit)

The analyzed grains associated with liandratite contain 53.6-55.7 wt $\% \mathrm{Nb}_{2} \mathrm{O}_{5}, 3.2-6.5 \mathrm{wt} \% \mathrm{Ta}_{2} \mathrm{O}_{5}, 2.1-6.5 \mathrm{wt} \%$ $\mathrm{TiO}_{2}$, up to $0.8 \mathrm{wt} \% \mathrm{P}_{2} \mathrm{O}_{5}$ and 1.6-5.6 wt $\% \mathrm{UO}_{2}$ (Table 3).

Only a single grain of polycrase- $(\mathrm{Y})$ was found together with liandratite. The content of $\mathrm{Nb}\left(13.3-22.5 \mathrm{wt} \% \mathrm{Nb}_{2} \mathrm{O}_{5}\right)$ and $\mathrm{Ta}\left(13.2-23.8 \mathrm{wt} \% \mathrm{Ta}_{2} \mathrm{O}_{5}\right)$ in this grain is quite high compared to $\mathrm{Ti}\left(16.9-19.0 \mathrm{wt} \% \mathrm{TiO}_{2}\right.$, see Fig. 4); the content of $\mathrm{W}\left(2.9-3.3 \mathrm{wt} \% \mathrm{WO}_{3}\right)$ is rather typical of the Karkonosze $\mathrm{Nb}$-Ta-Ti minerals, as is the content of $\mathrm{U}\left(2.9-8.1 \mathrm{wt} \% \mathrm{UO}_{2}\right)$.

The last-mentioned possible precursors are minerals with the composition of the pyrochlore group. These phases are formed as a result of the multistage alteration of various $\mathrm{Nb}$-Ta-Ti oxide minerals (i.e. fergusonite) in the way described by Ercit (2005); usually with loss of A-site cations, Si addition and hydration. A similar alteration affects ixiolite. Sometimes newly formed secondary phases belonging to this group with high contents of $\mathrm{Pb}$, $\mathrm{Bi}$ or $\mathrm{U}$ are present. The relationship between them and liandratite is rather unclear. The composition of minerals of the pyrochlore group together with $\mathrm{Pb}-, \mathrm{Bi}-, \mathrm{U}$-rich phases is as follows: 21.9-38.7 wt $\% \mathrm{Nb}_{2} \mathrm{O}_{5}, 5.5-23.6 \mathrm{wt} \% \mathrm{Ta}_{2} \mathrm{O}_{5}, 1.2-9.9 \mathrm{wt} \% \mathrm{TiO}_{2}$ and up to $1.6 \mathrm{wt} \% \mathrm{WO}_{3}$. Analyses reveal a very high content of silica (2.7-14.2 $\mathrm{wt} \% \mathrm{SiO}_{2}$ ) and in specific grains a high content of $\mathrm{Pb}$ (up to $16.4 \mathrm{wt} \% \mathrm{PbO}$ ) and sometimes $\mathrm{Bi}$ (up to $7.5 \mathrm{wt} \%$ $\mathrm{Bi}_{2} \mathrm{O}_{3}$ ) and $\mathrm{P}_{2} \mathrm{O}_{5}\left(4.6-9.2 \mathrm{wt} \% \mathrm{P}_{2} \mathrm{O}_{5}\right)$. The content of $\mathrm{U}$ is very variable and ranges from 0.9 to $12.7 \mathrm{wt} \% \mathrm{UO}_{2}$. Representative analyses of $\mathrm{Pb}$ - and Bi-rich minerals of the pyrochlore group are given in Table 3 (grains Sn\#2-11 and Sn2-5; see also Fig. 3f).

It seems that in the Karkonosze pluton there is no specific mineral which would be more susceptible to alteration than the others and the formation of liandratite depends only on the availability of relevant species in the pegmatite. Therefore liandratite in Karkonosze pegmatites possibly forms mostly after fergusonite since other possibly Nb-Ta-Ti oxide precursors occur much less frequently.

\section{Chemical similarity to uranopyrochlores}

Liandratite seems to be compositionally similar to uranopyrochlore (Atencio et al. 2010) in terms of the main elements; however, it has a different U oxidation state. According to the currently proposed nomenclature of the pyrochlore supergroup (Atencio et al. 2010), uranopyrochlore is a member of the pyrochlore group, with $\mathrm{U}^{4+}$ as the dominant cation at the A-site, assuming that $4^{+}$-valence cations prevail over other valence groups at this site and not regarding the dominant anion at the Y-site. It is still a somewhat theoretical mineral. The reason is the absence in the literature of an analysis meeting the current nomenclature rules. As previously mentioned, the dominant valence rule regarding the $\mathrm{U}$ content in the A-site is in fact met only by analysis 9 from Chibiny (Chakhmouradian and Mitchell 2002).

Due to the scarcity of good analyses of uranopyrochlore, the analyses of liandratite were compared to the theoretical composition of the following end-members: oxyuranopyrochlore $\square \mathrm{UNb}_{2} \mathrm{O}_{6} \mathrm{O}$ and oxyuranobetafite $\left(\square_{0.5} \mathrm{U}_{1.5}\right)_{2} \mathrm{Ti}_{2} \mathrm{O}_{6} \mathrm{O}$. This theoretical solid solution represents the most U-enriched members of the pyrochlore and betafite groups, respectively.

Data for U-rich members of the pyrochlore supergroup are plotted on Fig. 5, having been classified previously as uranpyrochlore and uranmicrolite (Hogarth 1977), partly given in Table S2. The content of $\mathrm{U}$ in the A-site in these analyses is $>20 \%$ of cations other than $\mathrm{Na}$ and $\mathrm{Ca}$. The theoretical compositions of oxyuranopyrochlore and oxyuranobetafite end-members are as follows: $50.4 \mathrm{wt} \% \mathrm{UO}_{2}, 49.6 \mathrm{wt} \% \mathrm{Nb}_{2} \mathrm{O}_{5}$ and $71.7 \mathrm{wt} \%$ $\mathrm{UO}_{2}, 28.29 \mathrm{wt} \% \mathrm{TiO}_{2}$, respectively. The change of composition between these two end-members should proceed along the line according to the exchange $0.5 \square+(\mathrm{Nb}, \mathrm{Ta})^{5+}{ }_{2} \leftrightarrow 0.5 \mathrm{U}^{4+}+2 \mathrm{Ti}^{4+}$, which borders the composition field of pyrochlores in the system $\mathrm{U}-\mathrm{Nb}+\mathrm{Ta}-\mathrm{Ti}$ (Fig. 5).

Normally, plots of the chemical composition of the U-rich phases of pyrochlore-betafite solid solution in the system $\mathrm{U}-\mathrm{Nb}+\mathrm{Ta}-\mathrm{Ti}$ should not exceed this boundary line. However, shifting the plot across the line is possible with a considerable contribution by $\mathrm{Al}$ and $\mathrm{Fe}^{3+}$ in comparison to Ti. Such a case is represented by analysis 9 from Chibiny (Chakhmouradian and Mitchell 2002). The significant presence of $\mathrm{Al}(1.80 \mathrm{wt} \%$ $\mathrm{Al}_{2} \mathrm{O}_{3} ; 0.18 \mathrm{apfu}$ ) compared to $\mathrm{Ti}\left(4.8 \mathrm{wt} \% \mathrm{TiO}_{2} ; 0.30 \mathrm{apfu}\right.$, Table S2) indicates an important contribution of a substitution into the B-site other than $(\mathrm{Nb}+\mathrm{Ta})^{5+} \leftrightarrow \mathrm{Ti}^{4+}$ with adequate compensations and slightly distorting the obtained image.

Liandratite should plot in the field restricted by the $\mathrm{UNb}_{2} \mathrm{O}_{8}-\mathrm{U}_{1.33} \mathrm{Ti}_{2} \mathrm{O}_{8}-\mathrm{U}_{2} \mathrm{TiO}_{8}$ end-members. The analysis 
Table 3 Chemical compositions of liandratite precursors

\begin{tabular}{|c|c|c|c|c|c|c|c|c|}
\hline \multirow[t]{2}{*}{ Constituents } & \multirow{2}{*}{$\begin{array}{l}\text { Polycrase-(Y) } \\
\text { Grod1-16-6 }\end{array}$} & \multirow{2}{*}{$\begin{array}{l}\text { Fergusonite-(Y) } \\
\text { LWD-nom-14-11 }\end{array}$} & \multicolumn{2}{|c|}{ Altered fergusonite-(Y) } & \multicolumn{3}{|c|}{$\begin{array}{l}\text { Mineral with composition of pyrochlore } \\
\text { group }\end{array}$} & \multirow{2}{*}{$\begin{array}{l}\text { Ixiolite } \\
\text { KS-mag5-2 }\end{array}$} \\
\hline & & & Sn3-8-6 & Rum3-nom-24-4 & Rum3-nom-28-7 & Sn\#2-11-3 & S2-5-2 & \\
\hline $\mathrm{WO}_{3}$ & 3.18 & 2.90 & 3.10 & 5.39 & 1.38 & 0.94 & 0.22 & 1.57 \\
\hline $\mathrm{P}_{2} \mathrm{O}_{5}$ & 0.00 & 0.00 & 0.00 & 0.06 & 0.14 & 5.21 & 9.18 & 0.20 \\
\hline $\mathrm{Nb}_{2} \mathrm{O}_{5}$ & 13.90 & 43.33 & 41.85 & 30.51 & 25.78 & 22.56 & 28.75 & 55.72 \\
\hline $\mathrm{Ta}_{2} \mathrm{O}_{5}$ & 23.76 & 3.00 & 9.06 & 6.34 & 12.38 & 22.51 & 18.04 & 6.54 \\
\hline $\mathrm{SiO}_{2}$ & 0.00 & 0.10 & 2.59 & 2.29 & 10.18 & 4.11 & 2.70 & 0.71 \\
\hline $\mathrm{TiO}_{2}$ & 18.68 & 0.83 & 3.93 & 5.56 & 9.87 & 2.88 & 1.16 & 6.51 \\
\hline $\mathrm{ZrO}_{2}$ & 0.00 & 0.00 & 0.00 & 0.24 & 1.82 & 0.31 & 0.17 & 0.31 \\
\hline $\mathrm{SnO}_{2}$ & 0.26 & 0.00 & 0.00 & 0.11 & 0.67 & 0.22 & 0.31 & 0.49 \\
\hline $\mathrm{ThO}_{2}$ & 1.08 & 0.68 & 1.96 & 3.37 & 4.14 & 0.51 & 0.39 & 0.81 \\
\hline $\mathrm{UO}_{2}$ & 7.24 & 2.52 & 2.24 & 5.35 & 12.72 & 5.67 & 10.06 & 5.58 \\
\hline $\mathrm{Al}_{2} \mathrm{O}_{3}$ & 0.00 & 0.00 & 0.38 & 0.00 & 0.61 & 2.19 & 4.75 & 0.95 \\
\hline $\mathrm{Sc}_{2} \mathrm{O}_{3}$ & 0.13 & 0.00 & 0.00 & 0.00 & 0.09 & 0.1 & 0.03 & 0.24 \\
\hline $\mathrm{Y}_{2} \mathrm{O}_{3}$ & 14.55 & 25.47 & 6.11 & 20.13 & 3.17 & 0.11 & 0.00 & 0.15 \\
\hline $\mathrm{La}_{2} \mathrm{O}_{3}$ & 0.00 & 0.00 & 0.16 & 0.00 & 0.68 & 0.20 & 0.13 & 0.00 \\
\hline $\mathrm{Ce}_{2} \mathrm{O}_{3}$ & 0.17 & 0.37 & 1.09 & 0.37 & 0.65 & 0.35 & 0.21 & 0.30 \\
\hline $\mathrm{Pr}_{2} \mathrm{O}_{3}$ & 0.00 & 0.00 & 0.29 & 0.07 & 0.44 & 0.00 & 0.00 & 0.00 \\
\hline $\mathrm{Nd}_{2} \mathrm{O}_{3}$ & 0.85 & 0.71 & 1.90 & 1.24 & 1.54 & 0.00 & 0.15 & 0.00 \\
\hline $\mathrm{Sm}_{2} \mathrm{O}_{3}$ & 0.51 & 0.68 & 1.51 & 0.94 & 0.81 & 0.00 & 0.00 & 0.00 \\
\hline $\mathrm{Eu}_{2} \mathrm{O}_{3}$ & 0.42 & 0.67 & 0.59 & 0.67 & 0.00 & 0.00 & 0.00 & 0.00 \\
\hline $\mathrm{Gd}_{2} \mathrm{O}_{3}$ & 0.88 & 1.45 & 1.74 & 1.86 & 0.85 & 0.00 & 0.00 & 0.00 \\
\hline $\mathrm{Tb}_{2} \mathrm{O}_{3}$ & 0.00 & 0.00 & 0.33 & 0.28 & 0.00 & 0.00 & 0.00 & 0.00 \\
\hline $\mathrm{Dy}_{2} \mathrm{O}_{3}$ & 1.78 & 2.94 & 2.28 & 2.68 & 1.10 & 0.00 & 0.00 & 0.00 \\
\hline $\mathrm{Ho}_{2} \mathrm{O}_{3}$ & 0.00 & 0.80 & 0.45 & 0.60 & 0.00 & 0.00 & 0.00 & 0.00 \\
\hline $\mathrm{Er}_{2} \mathrm{O}_{3}$ & 1.93 & 2.93 & 1.73 & 2.35 & 0.70 & 0.00 & 0.00 & 0.00 \\
\hline $\mathrm{Tm}_{2} \mathrm{O}_{3}$ & 0.58 & 0.00 & 0.00 & 0.00 & 0.00 & 0.00 & 0.000 & 0.00 \\
\hline $\mathrm{Yb}_{2} \mathrm{O}_{3}$ & 3.36 & 3.33 & 1.83 & 2.65 & 0.89 & 0.00 & 0.00 & 0.00 \\
\hline $\mathrm{Lu}_{2} \mathrm{O}_{3}$ & 0.59 & 0.61 & 0.33 & 0.43 & 0.00 & 0.00 & 0.00 & 0.00 \\
\hline $\mathrm{Bi}_{2} \mathrm{O}_{3}$ & n.a & n.a & n.a & n.a & $\mathrm{n} . \mathrm{a}$ & 5.88 & 0.00 & 0.00 \\
\hline $\mathrm{MgO}$ & 0.00 & 0.00 & 0.00 & 0.00 & 0.00 & 0.00 & 0.00 & 0.04 \\
\hline $\mathrm{CaO}$ & 0.86 & 0.67 & 5.01 & 1.98 & 0.92 & 0.80 & 0.28 & 0.19 \\
\hline $\mathrm{MnO}$ & 0.56 & 1.50 & 0.51 & 0.30 & 0.00 & 0.18 & 0.14 & 3.72 \\
\hline $\mathrm{FeO}^{\mathrm{a}}$ & 2.31 & 0.00 & 3.31 & 0.95 & 3.81 & 3.60 & 3.70 & 15.51 \\
\hline $\mathrm{PbO}$ & 0.00 & 0.00 & 0.58 & 0.00 & 0.46 & 15.76 & 10.86 & 0.00 \\
\hline $\mathrm{Na}_{2} \mathrm{O}$ & 0.03 & 0.00 & 0.00 & 0.00 & 0.00 & 0.00 & 0.00 & n.a \\
\hline $\mathrm{F}$ & 0.00 & 0.43 & 0.00 & 0.56 & 0.00 & n.a & 0.00 & n.a \\
\hline $\mathrm{O}=\mathrm{F}_{2}$ & 0.00 & -0.18 & 0.00 & -0.22 & 0.00 & 0.00 & 0.00 & 0.00 \\
\hline Total & 97.61 & 95.74 & 94.86 & 97.06 & 95.80 & 94.09 & 91.23 & 99.54 \\
\hline
\end{tabular}

All values are quoted in wt $\%$

n.a not analyzed

${ }^{\mathrm{a}}$ Total content of $\mathrm{Fe}$ is expressed as $\mathrm{FeO}$

of liandratite from Madagascar (Lumpkin and Ewing 1996, Table S2) plots within this field whereas that from Karkonosze plots mostly above the $\mathrm{UNb}_{2} \mathrm{O}_{8}-\mathrm{U}_{2} \mathrm{TiO}_{8}$ border due to the significant contribution of non-formula elements in the $\mathrm{B}$-site $\left(\mathrm{Al}, \mathrm{Fe}^{3+}\right)$ (Fig. 5). Analyses of liandratite from Egypt (Abd-el Naby 2009) show a significant dominance of Ti over
$\mathrm{Nb}+\mathrm{Ta}$ which suggests that it should not be considered as liandratite, which is essentially a Nb-dominant $\mathrm{U}$ oxide (Table S2).

A multiplicity of different substitutions in the pyrochloremicrolite-betafite groups yields a situation where in most cases in the system U-Nb+ Ta-Ti the compositional fields 


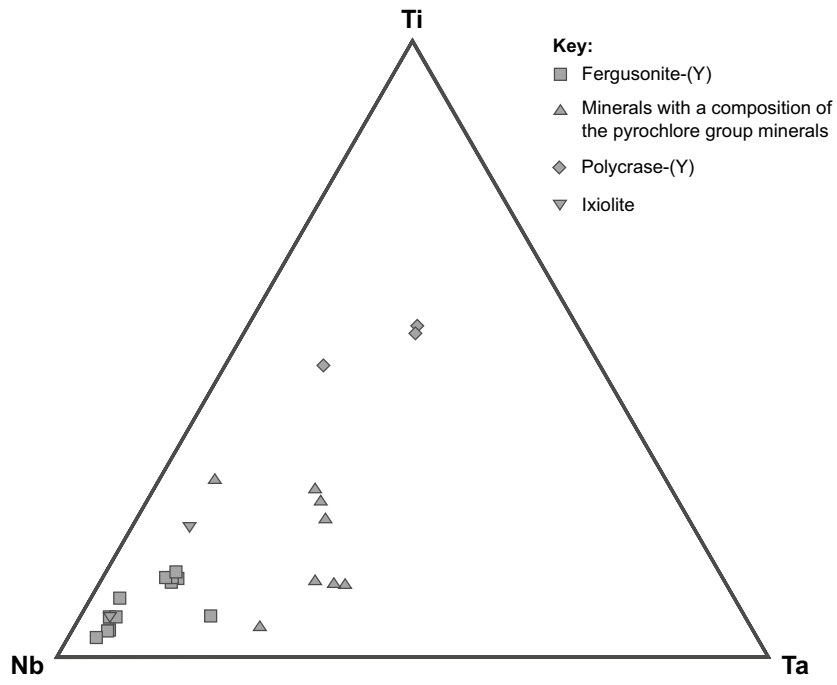

Fig. 4 Chemical composition of liandratite precursors plotted in the $\mathrm{Nb}-\mathrm{Ta}-\mathrm{Ti}$ triangle

of natural U-rich pyrochlores fall in the area below the $\square \mathrm{UNb}_{2} \mathrm{O}_{6} \mathrm{O}-\left(\square_{0.5} \mathrm{U}_{1.5}\right)_{2} \mathrm{Ti}_{2} \mathrm{O}_{6} \mathrm{O}$ boundary. This is evidence that distinguishing between the U-rich pyrochlore group minerals and liandratite in the U-Nb $+\mathrm{Ta}-\mathrm{Ti}$ system in most cases is possible, although ideal liandratite has the same theoretical $\mathrm{U}$ to $\mathrm{Nb}+\mathrm{Ta}$ ratio as oxyuranopyrochlore. Exceptions arise when the B-site in the pyrochlore group is significantly occupied by trivalent cations $-\mathrm{Al}, \mathrm{Fe}^{3+}$ (or by other cations different to $\mathrm{Nb}, \mathrm{Ta}, \mathrm{Ti}$ ), when the compositional plot could be shifted and fall in the liandratite field. Theoretically, analyses of liandratite trending toward the $\mathrm{U}_{1.33} \mathrm{Ti}_{2} \mathrm{O}_{8}$ endmember, due to the slightly overlapping composition fields of pyrochlore and liandratite, can also mistakenly be considered to be uranopyrochlore.

\section{Discussion}

The occurrence of liandratite suggests three possible modes of origin. One would be the direct replacement of a primary mineral (e.g. fergusonite) from the outer part toward its inner core along cracks and fissures present in the host (Fig. 3a-b). Occasionally between liandratite and the host mineral a transitional zone formed (Fig. 3b). Its chemical composition corresponds to the composition of the fergusonite at different alteration stages (mostly early or moderate) i.e. elevated $\mathrm{Ca}$ and decreased $\mathrm{Y}+\mathrm{REE}$ contents, minor Si addition. It seems that in this case liandratite incorporates almost the whole element set of its precursor, except for $\mathrm{Y}+\mathrm{REE}$ which are removed during alteration. In contrast to the observation of Lumpkin and Ewing (1996) in breakdown assemblages, discrete Ti-phases (e.g. rutile) were not found, even in altered Ti-rich phases such as polycrase-(Y). Only the excess $\mathrm{Fe}$ from Fe-rich phases (e.g. ixiolite) was transported out of liandratite and formed rims around it.

The second mode is possibly related to the breakdown of the precursor to two phases. These are a phase with the composition of pyrochlore group minerals (almost totally depleted in typical A-site cations) and liandratite, which occurs as $10-50 \mu \mathrm{m}$ inclusions.

In the Sosnówka\#1 pegmatite, a third, multistage-type alteration to liandratite was identified. It is based on the observation that the primary mineral is altered first to a phase with the composition of the pyrochlore group minerals

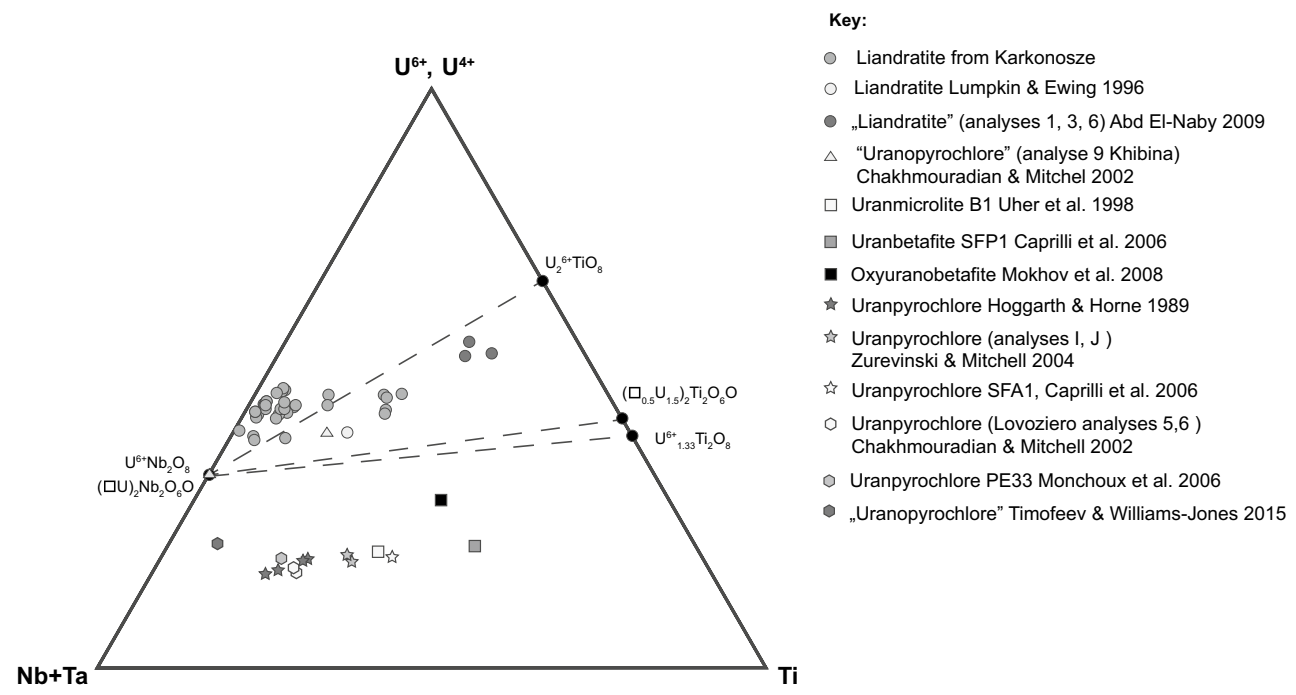

Fig. 5 Comparison of chemical composition of natural U-rich pyrochlores with liandratite from different localities in system U-Nb+Ta-Ti. Composition of U-rich pyrochlores is restricted by the ideal endmembers oxyuranopyrochlore, $\square \mathrm{UNb}_{2} \mathrm{O}_{6} \mathrm{O}$, and oxyuranobetafite, $\left(\square_{0.5} \mathrm{U}_{1.5}\right)_{2} \mathrm{Ti}_{2} \mathrm{O}_{6} \mathrm{O}$ whereas field of liandratite by $\mathrm{UNb}_{2} \mathrm{O}_{8}-\mathrm{U}_{2} \mathrm{TiO}_{8}$ -
$\mathrm{U}_{1.33} \mathrm{Ti}_{2} \mathrm{O}_{8}$. Details of presented data are given in Table S2. Please refer also to Hogarth and Horne (1989), Lumpkin and Ewing (1996), Uher et al. (1998), Chakhmouradian and Mitchell (2002), Zurevinski and Mitchell (2004), Caprilli et al. (2006), Monchoux et al. (2006), Mokhov et al. (2008), Abd El-Naby (2009), Timofeev and Williams-Jones (2015) 
or directly to $\mathrm{Pb}-, \mathrm{Bi}-$, U-rich pyrochlores, and then possibly to liandratite (i.e. Fig. 3c) Sometimes these late-formed pyrochlores occurred directly on the primary mineral and then were partly replaced by liandratite. However, the relationships between these pyrochlores and liandratite are not always clear. Obviously the pyrochlores mostly are replaced by liandratite (i.e. Fig. 3c); on the other hand, occasionally some occurrences indicate that they may have formed simultaneously.

Some textural features of the altered primary $\mathrm{Nb}-\mathrm{Ta}-\mathrm{Ti}$ phases are similar to those described by Poitrasson (2002) in allanite and Ruschel et al. (2010) in fergusonite from Madagascar and permits recognition of this type of alteration as fluid-driven. The alteration probably involved two events with different brine compositions with different oxidation potentials. The first event was related to the alteration of primary Nb-Ta-Ti minerals - removal mostly of the A-site cations, with the exception of $U$. The content of $U$ in the altered and non-altered parts of the investigated primary Nb-Ta-Ti minerals (mainly fergusonite and aeschynite-euxenite group minerals) is similar or slightly higher in the altered parts which suggests that $\mathrm{U}^{4+}$ was not converted to $\mathrm{U}^{6+}$ and also indirectly suggests that the fluids were not oxidising. During the second stage of alteration, U-bearing fluids favoured the formation of liandratite and U-rich pyrochlores. Possibly these were similar solutions to those forming epithermal $\mathrm{U}$ deposits in Karkonosze and numerous occurrences of pitchblende in low temperature hydrothermal assemblages within the granite. However, in this case the solutions were more oxidised, conceivably with an influence of meteoric water.

The contents of cations in the A position, significantly higher than the theoretical value, do not seem to be unusual for liandratite, as shown for the first time by Lumpkin and Ewing (1996). It is caused by the presence of cations other than pentavalent in the B-site, mainly $\mathrm{Ti}$, and the necessary charge compensation. The A position is able to accommodate additional cations as happens in the isostructural petscheckite $\mathrm{U}^{4+} \mathrm{Fe}^{2+}(\mathrm{Nb}, \mathrm{Ta})_{2} \mathrm{O}_{8}$. Hence, the chemical formula of liandratite is often presented as similar to that of petscheckite but with a vacancy in the $\mathrm{Fe}^{2+}$ position, namely $\mathrm{U}^{6+} \square(\mathrm{Nb}, \mathrm{Ta})_{2} \mathrm{O}_{8}$ (Černý and Ercit 1989).

The mechanism of incorporation of Ti into the structure is possibly allied to the incorporation of a significantly greater content of $U$ than the theoretical 1 apfu. This can be explained by the coupled heterovalent substitution expressed by the equation $2(\mathrm{Nb}, \mathrm{Ta})^{5+} \leftrightarrow \mathrm{U}^{6+}+\mathrm{Ti}^{4+}$ or $2(\mathrm{Nb}, \mathrm{Ta})^{5+} \leftrightarrow 1 / 3 \mathrm{U}^{6+}+2 \mathrm{Ti}^{4+}$ causing the shift of the chemical composition of liandratite toward the theoretical $\mathrm{U}_{2} \mathrm{TiO}_{8}$ and $\mathrm{U}_{1.33} \mathrm{Ti}_{2} \mathrm{O}_{8}$ end-members, respectively.

However, 2D plots show ambiguous trends. There is a significant negative correlation between $\mathrm{Ti}$ and $\mathrm{Nb}+\mathrm{Ta}$ with a trend close to 1:1 (Fig. 6a). The abundance of $U$ is rather weakly positively correlated with the content of Ti (Fig. 6b).
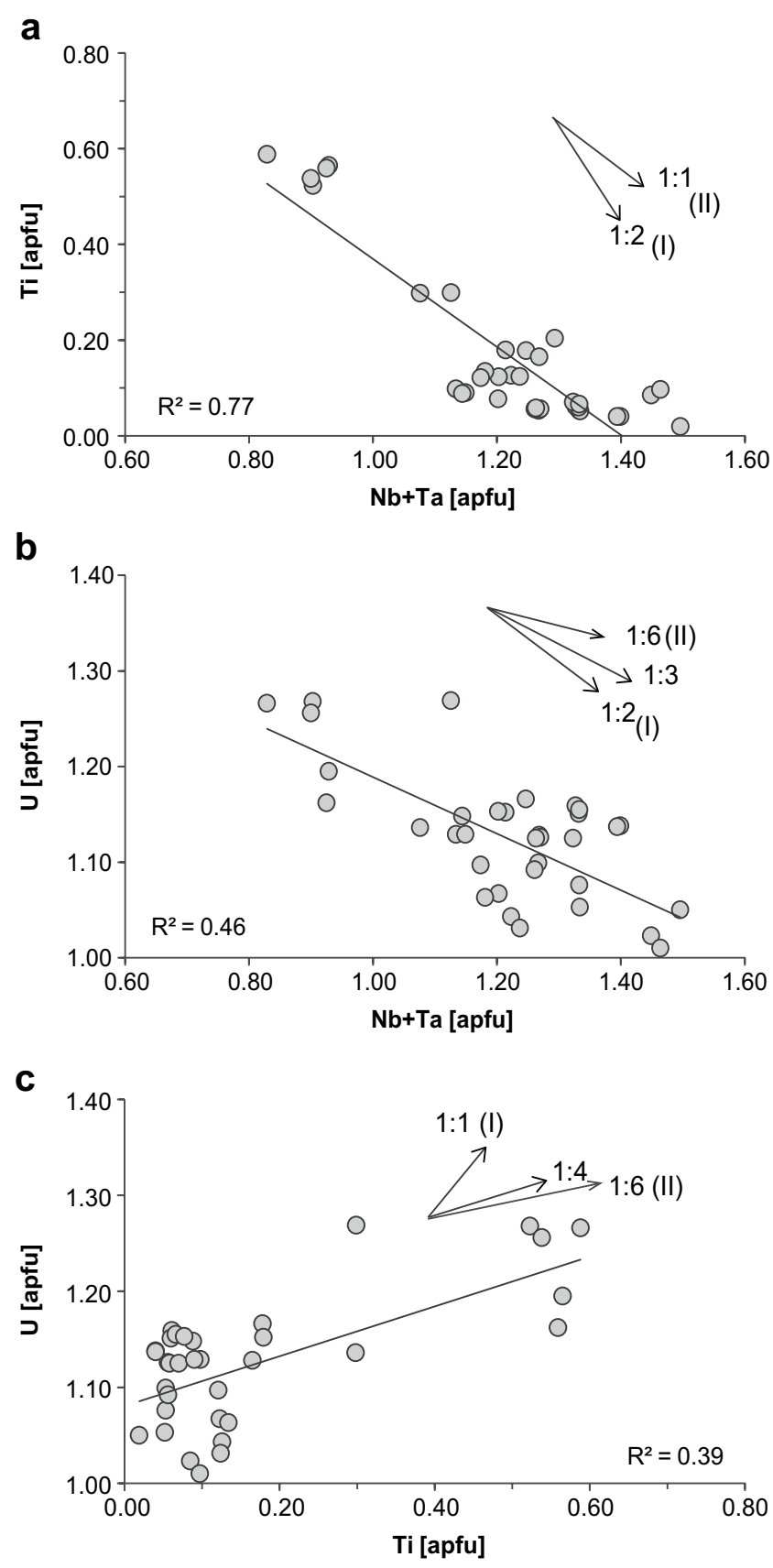

Fig. 6 Main chemical substitutions in liandratite. Arrows indicate trends of various ratios. Trends marked I and II are related to the substitutions: I $-2(\mathrm{Nb}, \mathrm{Ta})^{5+} \leftrightarrow \mathrm{U}^{6+}+\mathrm{Ti}^{4+} ; \mathrm{II}-2(\mathrm{Nb}, \mathrm{Ta})^{5+} \leftrightarrow 1 / 3 \mathrm{U}^{6+}+2 \mathrm{Ti}^{4+}$

The analyses plotted on a U vs Ti diagram show a significant scatter but with a positive trend ratio of approximately 1:4 (Fig. 6c). The relationships between $\mathrm{U}$ and $\mathrm{Nb}+\mathrm{Ta}$ show a weakly negative trend with a ratio close to $1: 3$ or 1:4. Additionally, it seems that analyses from various pegmatites differ in substitution patterns, which makes it difficult to indicate the main direction of substitution in the whole population. A rather weak set of correlations is possibly caused by the 


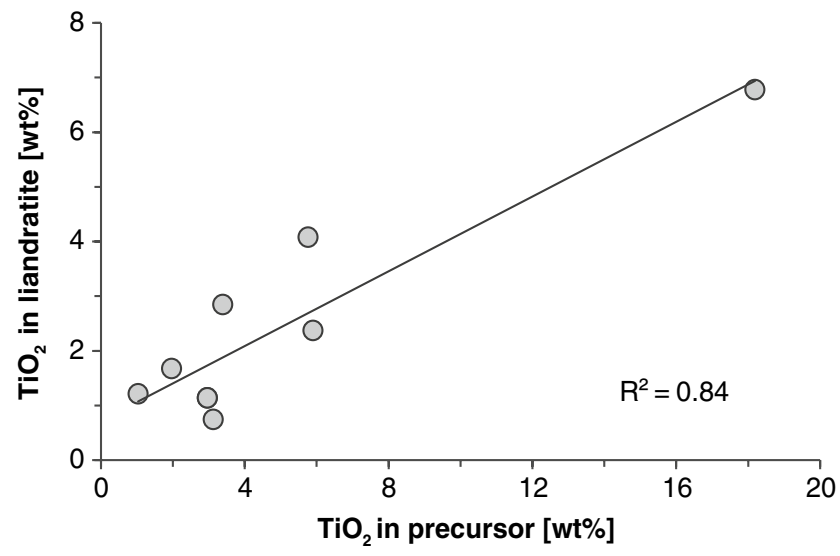

Fig. 7 Correlation between the mean content of $\mathrm{Ti}\left(\mathrm{wt} \% \mathrm{TiO}_{2}\right)$ in liandratite and its parent mineral

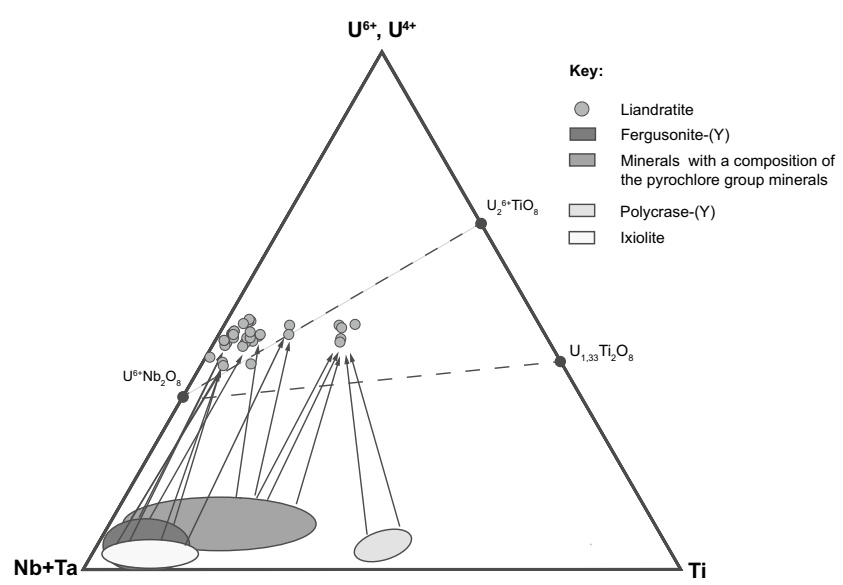

Fig. 8 Chemical composition of liandratite in the system $\mathrm{U}-(\mathrm{Nb}+\mathrm{Ta})-$ Ti. Arrows indicate dependency on chemical composition of the parent mineral and liandratite as its alteration product

limited number of analyses. On the other hand they express a more complex character of the cation exchange than that mentioned above.

Surplus Ti in liandratite, when compared to its ideal endmember, is related to its mineral precursor. There is a strong correlation between the mean content of $\mathrm{Ti}$ (expressed in $\mathrm{wt} \%)$ in the precursor and in the associated liandratite (Fig. 7). The excess of $U$ is at least partially and indirectly controlled by the amount of $\mathrm{Ti}$ in the precursor (Fig. 8). Liandratite formed by the breakdown of Ti-rich precursors (polycrase) is characterised by an elevated content of $U$ when compared to liandratite from the alteration of low-Ti minerals.

The analysed elements, occupying both A- and B-sites, mostly were found in liandratite (Lumpkin and Ewing 1996) and also in the composition of the isostructural and chemically similar petscheckite (Mücke and Strunz 1978; Tomašić et al. 2004). However, the presence of non-formula elements such as $\mathrm{Al}, \mathrm{Si}, \mathrm{P}$ and $\mathrm{W}$ in the structure of liandratite, sometimes in significant amounts, requires explanation.

The structure of $\mathrm{U}^{6+} \mathrm{Ta}_{2} \mathrm{O}_{8}$ given by Gasperin (1960) has not yet been verified and has even been questioned (Bush and Gruehn 1996). According to Gasperin's data, the A-site is in sixfold and B-site in eightfold coordination; the number of elements which could possibly occupy the B-position is limited when compared to other Nb-Ti-Ta oxides, e.g. the pyrochlore supergroup and fergusonite. According to Shannon (1976), Al, Si, P and W do not have as high coordination numbers as $\mathrm{Nb}, \mathrm{Ta}$ and $\mathrm{Ti}$. The difference between the ionic radii of $\mathrm{P}(0.38 \AA), \mathrm{Si}(0.4 \AA)$ in sixfold coordination and $\mathrm{Nb}(0.74 \AA)$ and Ta and Ti in eightfold coordination (Shannon 1976) is 49 and $46 \%$ respectively, and this means that they are too small to occupy this position. Although sixfold coordinated $\mathrm{Si}$ is known in synthetic silicate pyrochlores (Reid et al. 1977; Xu et al. 2011) they are stable only at high pressures. The role of $\mathrm{Si}$ frequently revealed in analyses is still intensively discussed. However the latest investigations of natural Si-bearing pyrochlores excluded the presence of $\mathrm{Si}^{4+}$ in the structure of this group of minerals (DumańskaSłowik et al. 2014).

The occurrence of $\mathrm{P}$ is a particular problem. It is rather seldom reported as a non-formula element in metamict $\mathrm{Nb}$ Ta-Ti minerals. However in some Karkonosze pegmatites, meso- and epithermal solutions were P-rich down to very low temperatures, as shown by precipitating phosphate minerals, mainly monazite-(Nd) and probably rhabdophane-(Nd) together with manganese oxides and hydroxides. Therefore, the occasional presence of small amounts of $\mathrm{P}$ together with $\mathrm{Si}$ and others in the matrix of heavy altered primary $\mathrm{Nb}-\mathrm{Ta}-$ Ti minerals and in liandratite is not surprising.

In the case of $\mathrm{Al}(0.54 \AA)$ and $\mathrm{W}(0.6 \AA)$ the differences are $28 \%$ and $21 \%$, respectively, which allows only limited substitution, according to Goldschmidt's rules (Misra 2012). Hence, the presence of $\mathrm{W}$ in the structure with a maximum content of 0.03 apfu seems to be very probable. Possibly $\mathrm{Al}$ is also located within the structure but in significantly lower amounts than the maximum of 0.28 apfu mentioned above. Therefore only a small part of the $\mathrm{Al}$ found by microprobe analysis possibly occupies the B-site; the rest is not structurally located.

The presence of non-formula elements in various radiation-damaged minerals (e.g. zircon and pyrochlore supergroup minerals) has been extensively investigated (e.g. Geisler et al. 2003; Rayner et al. 2005; Bonazzi et al. 2006; Dumańska-Słowik et al. 2014). In various minerals of the above-named assemblage there are different elements; however, they share a common feature-they all concentrate in the intensively radiation-damaged, amorphous domains outside the crystal structure of the host mineral. The non-formula elements found in the analyses, namely 
$\mathrm{P}^{5+}, \mathrm{Si}^{4+}$ and the majority of $\mathrm{Al}^{3+}$, due to their inconsistency with the structure of liandratite and by analogy with other metamict minerals, should be treated as elements dispersed in the amorphous matrix (Geisler et al. 2003; Rayner et al. 2005) or as sub-microscopic intergrowths of alumosilicates or phosphates.

Liandratite in Karkonosze pegmatites is a secondary mineral but a detailed explanation of its origin may present some issues. Due to the method of investigation used, crushing, milling etc., it was difficult to obtain the full textural context of the occurrence and as a consequence the origin of the liandratite.

\section{Concluding remarks}

Liandratite is a complex secondary mineral formed as a product of alteration of $\mathrm{Nb}$-Ta-Ti oxides such as fergusonite-(Y), minerals from the aeschynite-euxenite group and ixiolite. Apparently, during the alteration of Ti-poor primary minerals, e.g. fergusonite, ixiolite, and the alteration of Ti-rich phases (polycrase), all the Ti is incorporated into liandratite. Incorporation of Ti caused the additional incorporation of $\mathrm{U}$ into the structure. Nevertheless, neither of the two theoretical solid solutions fully explains the presence of the significant $U$ excess in liandratite from Karkonosze.

The theoretical U-rich end-member of the pyrochlore group, namely oxyuranopyrochlore $\square \mathrm{U}^{4+} \mathrm{Nb}_{2} \mathrm{O}_{6} \mathrm{O}$, has a similar composition to the ideal liandratite, with the exception of different $\mathrm{U}$ oxidation states. Its theoretical solid solutions with oxyuranobetafite, $\left(\square_{0.5} \mathrm{U}^{4+}{ }_{1.5}\right)_{2} \mathrm{Ti}_{2} \mathrm{O}_{6} \mathrm{O}$, present the most $\mathrm{U}$-enriched pair of end-members in the pyrochlore supergroup which can be chemically similar (with regard to the $\mathrm{U}$ oxidation state) to liandratite. In the system $\mathrm{U}-\mathrm{Nb}+\mathrm{Ta}-\mathrm{Ti}$, the theoretical composition fields of the both groups of minerals, pyrochlores and liandratite, slightly overlap, especially toward the Ti apex. Nevertheless, contemporary reviews of natural U-bearing pyrochlores point out that their compositions usually fall far below the boundary line. The only exceptions are analyses with significant contents of elements other than $\mathrm{Nb}, \mathrm{Ta}$, $\mathrm{Ti}$ in the B-site which can fall in the liandratite field. On the other hand theoretical liandratite with a significant contribution of $\mathrm{U}^{6+}{ }_{1.33} \mathrm{Ti}_{2} \mathrm{O}_{8}$ can be mistakenly identified as pyrochlore.

So far the number of liandratite analyses is rather insufficient, its crystallochemical model (scheme) almost unknown and oxyuranopyrochlore is still only a theoretical end-member of the pyrochlore group. Therefore the data presented here are only a first approach to a complete description of the Karkonosze liandratite and to its chemical relationship with the pyrochlore supergroup minerals.
Acknowledgements The author would like to thank Piotr Dzierżanowski and Lidia Jeżak from the Inter-Institutional Analytical Laboratory for Minerals and Synthetic Substances (Faculty of Geology, University of Warsaw) for assistance with the EPMA analyses. The project was supported by the grant from the Faculty of Geology, University of Warsaw BSt 176804. The support from the analytical facilities of the project RPO-WM 2007-2013 "Modernization and equipment supplement of laboratories at Faculty of Geology, University of Warsaw, for crucial environmental geo-engineering research and development of Mazovia: Stage 1" is acknowledged. Author also is very indebted to Ray MacDonald for language correction of the manuscript. Constructive comments of two anonymous experts and journal editor Fernando Gervilla are gratefully acknowledged.

Open Access This article is distributed under the terms of the Creative Commons Attribution 4.0 International License (http://creativecommons.org/licenses/by/4.0/), which permits unrestricted use, distribution, and reproduction in any medium, provided you give appropriate credit to the original author(s) and the source, provide a link to the Creative Commons license, and indicate if changes were made.

\section{References}

Abd El-Naby HH (2009) Role of geochemical alteration on the formation of secondary Zr- and U-bearing minerals in El Asthan trachyte, central Eastern Desert, Egypt. J Mineral Petrol Sci 104:37-51

Atencio D, Andrade MB, Christy AG, Gieré R, Kartashov PM (2010) The pyrochlore supergroup of minerals: nomenclature. Can Mineral 48:673-698

Beurlen H, Barreto SB, Silva D, Wirth R, Olivier P (2007) Titanian ixiolite-niobian rutile intergrowths from the Borborema Pegmatitic Province, northeastern Brazil. Can Mineral 45:1367-1387

Bonazzi P, Bindi L, Zoppi M, Capitani GC, Olmi F (2006) Singlecrystal diffraction and transmission electron microscopy studies of "silicified" pyrochlore from Narssârssuk, Julianehaab district, Greenland. Am Mineral 91:794-801

Borkowska M (1966) Petrography of the Karkonosze granite. Geol Sudet 2:7-119

Bush J, Gruehn R (1996) Synthese und Struktur von $\mathrm{M}_{4} \mathrm{Ta}_{18} \mathrm{O}_{53}(\mathrm{M}=$ $\mathrm{Th}, \mathrm{U})$; die ersten Vertreter eines neuen Strukturtyps à la Jahnberg. Z Anorg Allg Chem 622:640-648

Caprilli E, Della Ventura G, Williams CT, Parodi GC, Tuccimei P (2006) The crystal chemistry of non-metamict pyrochlore-group minerals from Latium, Italy. Can Mineral 44:1367-1378

Černý P, Ercit TS (1989) Mineralogy of niobium and tantalum: crystal chemical relationships, paragenetic aspects and their economic implication. In: Möller P, Černý P, Saupé F (eds) Lanthanides, tantalum and niobium. Springer, Berlin, pp 27-79

Černý P, Ercit TS (2005) The classification of granitic pegmatites revisited. Can Mineral 43:2005-2026

Černý P, London D, Novák M (2012) Granitic pegmatites as reflection of their sources. Elements 8:289-294

Chakhmouradian AR, Mitchell RH (2002) New data on pyrochloreand perovskite-group minerals from the Lovozero alkaline complex, Russia. Eur J Mineral 14:821-836

Dumańska-Słowik M, Pieczka A, Tempesta G, Olejniczak Z, Heflik W (2014) "Silicified" pyrochlore from nepheline syenite (mariupolite) of the Mariupol Massif, SE Ukraine: a new insight into role of silicon in the pyrochlore structure. Am Mineral 99:2008-2017

Ercit TS (2005) Identification and alteration trends of granitic-pegmatite-hosted (Y,REE,U,Th)-(Nb,Ta,Ti) oxide minerals: a statistical approach. Can Mineral 43:1291-1303 
Galliski MA, Márquez-Zavalía MF, Roquet MF (2009) The Nb-Ta-U oxide minerals from María Elena Pegmatite, San Luis, Argentina. Estud Geol 19:127-130

Gasperin M (1960) Contribution a l'étude de quelques oxydes doubles que forme le tantale avec l'étain, l'uranium et le calcium; application à la cassiterite et à la betafite. Bull Soc Fr Mineral Cr 83:1-21

Geisler T, Pidgeon RT, Kurtz R, van Bronswijk W, Schleicher H (2003) Experimental hydrothermal alteration of partially metamict zircon. Am Mineral 88:1496-1513

Hogarth DD (1977) Classification and nomenclature of the pyrochlore group. Am Mineral 62:403-410

Hogarth DD, Horne JET (1989) Non-metamict uranoan pyrochlore and uranpyrochlore from tuff near Ndale, Fort Portal area, Uganda. Mineral Mag 53:257-262

Kozłowski A, Sachanbiński M (2007) Karkonosze intragranitic pegmatites and their minerals. In: Kozłowski A, Wiszniewska J (eds) Granitoids in Poland, AM Monograph No. 1. KMN PAN-WG UW, Warszawa, pp 155-178

Kristiansen R (2006) Liandratitt $-\mathrm{U}^{6+}(\mathrm{Nb}, \mathrm{Ta})_{2} \mathrm{O}_{8}-$ fra Herrebøkasa, Østfold. Stein 33(2):28

Kryza R, Pin C, Oberc-Dziedzic T, Crowley QG, Larionov A (2014) Deciphering the geochronology of a large granitoid pluton (Karkonosze granite, SW Poland): an assessment of U-Pb zircon SIMS and $\mathrm{Rb}-\mathrm{Sr}$ whole-rock dates relative to U-Pb zircon CA-IDTIM. Int Geol Rev 56:756-782

Lumpkin GR (2001) Alpha-decay damage and aqueous durability of actinide host phases in natural systems. J Nucl Mater 289:136-166

Lumpkin GR, Ewing RC (1996) Geochemical alteration of pyrochlore group minerals: betafite subgroup. Am Mineral 81:1237-1248

Martin RF, De Vito C (2005) The patterns of enrichment in felsic pegmatites ultimately depend on tectonic setting. Can Mineral 43:2027-2048

Matyszczak W (2013) Minerały niobu i tantalu w asocjacjach pegmatytowych NE części masywu Karkonoszy. [Niobium and tantalum minerals in pegmatite associations of NE part of Karkonosze massif]. Dissertation, University of Warsaw

Matyszczak W (2014) Liandratite from Karkonosze pegmatites, Sudetes, SW Poland. CEMC 2014 Book of Abstracts, Skalský Dvůr, Czech Republic., April 23-26, 2014, 92-93

Mikulski SZ (2007) Metal ore potential of the parent magma of granite - the Karkonosze massif example. In: Kozłowski A, Wiszniewska $\mathrm{J}$ (eds) Granitoids in Poland, AM Monograph No. 1. KMN PANWG UW, Warszawa, pp 123-145

Misra KC (2012) Introduction to geochemistry: principles and applications. Wiley-Blackwell

Mokhov AV, Kartashov PM, Bogatikov OA, Ashikhmina NA, Magazina LO, Koporulina EV (2008) Fluorite, hatchettolite, calcium sulfate, and bastnasite-(Ce) in the lunar regolith from Mare Crisium. Dokl Earth Sci 422(1):1178-1180

Monchoux P, Fontan F, Parseval P, de Martin RF, Wang RC (2006) Igneous albititic dikes in orogenic lherzolites, Western Pyrenees, France: a possible source for corundum and alkali feldspar xenocrysts in basaltic terranes. I. Mineral associations. Can Mineral 44:817-842
Mücke H, Strunz H (1978) Petscheckite and liandratite, two new pegmatite minerals from Madagascar. Am Mineral 63:941-946

Pieczka A, Szuszkiewicz A, Szełęg E, Janeczek J, Nejbert Krzysztof (2015) Granitic pegmatites of the Polish part of the Sudetes (NE Bohemian massif, SW Poland). In: Gadas P, Novak M, Szuszkiewicz A, Cempírek J (eds) PEG 2015: 7th international symposium on Granitic pegmatites: June 17-19 2015, Książ, Poland; June 14-17, 2015 Czech Republic; June 20-21, 2015, Poland: fieldtrip guidebook Tigris Zlín, pp 73-103

Poitrasson F (2002) In situ investigation of allanite hydrothermal alteration: examples from calc-alkaline and anorogenic granites of Corsica (southeast France). Contrib Mineral Petrol 142:485-500

Pouchou IL, Pichoir F (1985) "PAP" $(\phi-\rho-Z)$ ) procedure for improved quantitative microanalysis. In: Armstrong IT (ed) Microbeam analysis. San Francisco Press, San Francisco, pp 104-106

Rayner N, Stern RA, Carr D (2005) Grain-scale variations in trace element composition of fluid-altered zircon, Acasta Gneiss complex, northwestern Canada. Contrib Mineral Petrol 148:721-734

Reid AF, Li C, Ringwood AE (1977) High-pressure silicate pyrochlores, $\mathrm{Sc}_{2} \mathrm{Si}_{2} \mathrm{O}_{7}$ and $\mathrm{In}_{2} \mathrm{Si}_{2} \mathrm{O}_{7}$. J Solid State Chem 20:219-226

Ruschel K, Nasdala L, Rhede D, Wirth R, Lengauer CL, Libowitzky E (2010) Chemical alteration patterns in metamict fergusonite. Eur J Mineral 22:425-433

Shannon RD (1976) Revised effective ionic radii and systematic studies of interatomic distances in halides and chalcogenides. Acta Crystallogr A 32:751-767

Słaby E, Martin H (2008) Mafic and felsic magma interaction in granites: the Hercynian Karkonosze Pluton (Sudetes, Bohemian Massif). J Petrol 49:353-391

Timofeev A, Williams-Jones AE (2015) The origin of niobium and Tantalum mineralization in the Nechalacho REE deposit, NWT. Canada Econ Geol 110:1719-1735

Tomašić N, Raade G, Bermanec V (2004) REE-bearing petscheckite from Tiltvika, Nordland, Norway, and its heating products. Neues Jb Miner Monat 4:163-175

Uher P, Černý P, Chapman R, Határ J, Miko O (1998) Evolution of Nb, Ta-oxide minerals in the Prašivá granitic pegmatites, Slovakia. II. External hydrothermal $\mathrm{Pb}, \mathrm{Sb}$ overprint. Can Mineral 36:535-545

Wise MA, Černý P, Falster AU (1998) Scandium substitution in columbite-group minerals and ixiolite. Can Mineral 36:673-680

Xu J, Ito E, Yamazaki D, Guo X, Wu X (2011) Synthesis and crystal chemical characterization of the pyrochlore type $\mathrm{MgZrSi}_{2} \mathrm{O}_{7}$. Mater Chem Phys 128:410-412

Žák J, Klomínský J (2007) Magmatic structures in the Krkonoše-Jizera Plutonic Complex, Bohemian Massif: evidence for localized multiphase flow and small-scale thermal-mechanical instabilities in a granitic magma chamber. J Volcanol Geotherm Res 164:254-267

Žák J, Verner K, Sláma J, Kachlík V, Chlupáčová M (2013) Multistage magma emplacement and progressive strain accumulation in the shallow-level Krkonoše-Jizera plutonic complex, Bohemian Massif. Tectonics 32:1493-1512. https://doi.org/10.1002/tect.20088

Zurevinski SE, Mitchell RH (2004) Extreme compositional variation of pyrochlore-group minerals at the Oka Carbonatite Complex, Quebec: evidence of magma mixing? Can Mineral 42:1159-1168 